\title{
Fen Bilimleri Ders Kitaplarındaki Fizik Örneklerinin Karşılaştırılması
}

\section{Tolga SAKA* ve Tufan İNALTEKİN**}

Özet: Bu çalışmada, Türkiye’deki ortaokul 5. sınıf Fen Bilimleri derslerinde okutulmak üzere yazılmış kitaplardaki fizik konularının öğretimi için kullanılan örnek türlerinin karşılaştırılması amaçlanmıştır. Bu kapsamda, 2020-2021 eğitim-öğretim döneminde Millî Eğitim Bakanlığ1 Talim Terbiye Kurulu Başkanlığı tarafından ortaokullarda okutulmak üzere onaylanmış üç adet, 5. sınıf Fen Bilimleri ders kitabındaki fizik konularına ait örnekler incelenmişstir. Çalışma, nitel araştırma yöntemlerinden doküman analizini içermektedir. 5. sınıf Fen Bilimleri ders kitaplarındaki fizik konularının öğretiminde kullanılan örnek türlerini karşılaştırmak için örnek sınıflandırma sistematiği kullanılmıştır. Çalışmanın bulguları, 5. sınıf Fen Bilimleri ders kitaplarının her üçünde de fizik konularının öğretimi için, büyük oranda standart örnek türlerine ve daha az sayıda ise başlangıç ve geliştirici örnek türlerine yer verildiği tespit edilmiştir. Buna karşın uç örnekler, örnek dışı örnekler ve karşıt örneklere ise, kitapların üçünde de yer verilmediği görülmüştür. Ayrıca her üç kitapta da standart örnek türleri bakımından, fizik konusuna ilişkin yapılan tanımın ne anlama geldiğini ifade eden prototip örneklerin büyük oranda tercih edildiği belirlenmiştir. Bu çalışmanın sonuçları, incelenen 5. sınıf Fen Bilimleri ders kitaplarındaki fizik konularının öğretimi için kullanılan örneklerin çeşitliliğinde, eksikliklerin olduğuna ve dolayısıyla kitaplardaki fizik örneklerinin yenilenmesi gerektiğine işaret etmektedir.

Anahtar Kelimeler: Fen bilimleri öğretimi, Ders kitapları, Örnek türleri, Doküman analizi

\section{Comparison of Physics Examples in Science Textbooks}

Abstract: The aim of this study was to compare the types of examples given in secondary school 5th grade textbooks used for teaching sciences subjects in Turkey. Thus, three examples of physics subjects given in the 5th grade science textbooks approved to be taught in secondary schools by the Ministry of National Education Board of Education and Discipline in the 2020-

\footnotetext{
* Dr. Öğr. Üyesi, Kafkas Üniversitesi, Dede Korkut Eğitim Fakültesi, Matematik ve Fen Bilimleri Eğitimi Bölümü, Fen Bilgisi Eğitimi Anabilim Dalı, Email:tsaka61@gmail.com, Orcid No: 0000-0002-0042-0836.

** Doç. Dr., Kafkas Üniversitesi, Dede Korkut Eğitim Fakültesi, Matematik ve Fen Bilimleri Eğitimi Bölümü, Fen Bilgisi Eğitimi Anabilim Dal1, Email: inalteintufan@gmail.com, Orcid No: 0000-0002-3843-7393
} 
2021 academic year were examined. The document analysis method, one of the qualitative research methods, was used in this study. Sample classification systematic was used to compare the types of examples used in teaching physics subjects in 5th grade science textbooks. According to the results of this study, mostly standard examples and a smaller number of beginner and improving examples were used for the teaching of physics subjects in all three of the 5th grade science textbooks. It was seen that extreme, non-exemplary and counter examples were not included in all three books. In terms of standard examples, prototype examples expressing the meaning of the definitions regarding the physics were mostly preferred in all three books. In conclusion, the study indicated that there are deficiencies in the variety of examples used for teaching physics subjects in the 5th grade science textbooks evaluated; therefore, the physics examples in the books should be renewed.

Keywords: Science teaching, Textbooks, Types of examples, Document analysis

\section{Giriş}

Fen bilimleri eğitiminde öğrencilerin öğrendikleri bilgilerin niteliğini birçok değişken biçimlendirmektedir. $\mathrm{Bu}$ değişkenlerden biri, öğrencilerin kavramlar hakkında farklı kaynaklardan bilgiler elde etmeleri olarak ifade edilebilir. Fen bilimlerinde öğrencilerin öğrendikleri bilgilerin niteliğini belirleyen en temel kaynak ders kitaplarıdır (Işık, 2008; Sadoski, 2001). Stern ve Roseman (2004), öğretmenlerin alan deneyimlerinin dişında öğretim süreçlerinde en çok değer verdikleri ve güvendikleri kaynağın ders kitapları olduğunu ifade etmişlerdir. Ders kitapları, gerçek dünyadaki oluşumlar ve bilimsel teoriler arasındaki bağlantıları tanımlar, öğretilecek içeriği ve öğretim yöntemleri için temel kuralları belirler (Ahtineva, 2005). Bu kitaplar, öğrencilerin bireysel faaliyetlerinin her zaman bir parçasıdır ve öğrenme sürecinin tüm aşamalarında gereklidir (Devetak ve Vogrinc, 2013). Pek çok öğretmen için ders kitabı, tüm dönem boyunca konuların nasıl verildiği ve neyin değerlendirildiğini içeren öğretimleri şekillendirir (Başer, 2012; Kavcar ve Erdem, 2017).

Fen bilimleri ders kitapları, öğrencilerin fen içeriği ve bilimsel süreç becerilerini öğrenmeleri için firsat sağlayan çok değerli bir öğretim aracıdır (Bansiong, 2019; Morris, Masnick, Baker ve Junglen, 2015). Fen bilimleri öğretiminde zaman ve kaynak kısıtlamalarının gerçekliği ve uzman olmayan fen bilimleri öğretmenlerinin, konu alanını öğretme oranlarının yüksek olması, ders kitaplarına aşırı güvenilmesine neden olmaktadır (Mcdonald, 2016). Ders kitapları Fen Bilimleri derslerinin yapısını ve yönünü büyük ölçüde etkilemektedir. Öğrenciler genellikle fen bilimlerinde içerik alanları hakkında birçok yanlış anlamalara sahip 
olmaktadırlar. Öğrencilerin bilimdeki yanlış anlayışlara sahip olmalarının tek nedeni ders kitapları olmasada, ders kitapları öğrencilerin aldığı bilimsel bilgilerin büyük bir kısmını temsil etmektedir (Binns, 2013). Bu kitaplarda önerilen kavramlar, tanımlar, prosedürler ve etkinlikler üzerine birçok tartışma vardır. Ders kitaplarında, neyin vurgulanması gerektiğini sunmanın en iyi yolu, doğru ve etkili ifadeleri kullanmaktan geçer. Fen bilimleri derslerinde konulara ait kavramları daha anlaşılır hale getirmek için örnek kullanmak oldukça önemlidir. Örnek, kavramlara ait tanımların yanı sıra kavramlara ait olmayan durumların açıklanması için kullanılan özel durumlardır (Alkan, 2016). Fen bilimleri ders kitaplarında tercih edilen konu örnekleri, öğrencilerin bilimsel bilgiyi doğru ve daha anlaşılır biçimde edinimlerini etkilemektedir. Ne yazıkki, yanlış anlamaya neden olabilir birçok hatalı ders kitabı örneği vardır (King, 2010; Zajkov, Gegovska-Zajkova ve Mitrevski, 2017). Ders kitapları, fen kavramlarını yetersiz bir şekilde sunduğunda ve açıkladığında, öğrenciler bilimle ilgili pek çok yanlış anlamaya sahip olmakta ve bilimi öğrenmekte zorlanmaktadırlar (Abd-El-Khalick, 2002; Morris ve diğ., 2015).

Ülkelerdeki müfredat değişikliği, yeni içerik, öğrenme teorileri ve değerlendirme içeren yeni bir pedagojik felsefeyi gerektirir. Fen bilimleri ders kitapları, eğitim reformlarında uzun süredir müfredatın kilit bir parçasıdır (Park ve Lavonen, 2013). Ülkemizde 2018 yılında fen bilimleri öğretim programı, bir değişime uğramıştır. Bu kapsamda, Fen Bilimleri ders kitaplarının içerikleride yeniden düzenlenmiştir. Ders kitapları, fen bilimleri eğitiminde çok önemli rol oynadığından, eğitim reformundaki eğilimleri yansıtmalıdır. $\mathrm{Bu}$ nedenle, Türkiye'nin Fen Bilimleri ders kitaplarında içeriğin nasıl karakterize edildiğini araştırmak önem arz etmektedir. Ders kitaplarının fen bilimleri eğitiminde oynadığı önemli rol nedeniyle, çok sayıda çalışmada, ders kitapları çeşitli açılardan değerlendirmiştir (Akcay, Kapici ve Akcay, 2020; Li, Tan, Shen, Hu, Chen ve Wang, 2020). İlgili alan yazında, Fen Bilimleri ders kitaplarının, çoğunlukla konu etkinlikleri (Bakırcı ve Öçsoy, 2017; İnaltekin, Özyurt ve Akçay, 2012), Bloom taksonomisi (Akçay, Akçay ve Kahramanoğlu, 2019; Akcay, Akcay ve Inaltekin, 2018), bilimin doğası (Abd-El-Khalick ve diğ., 2017; McDonald ve Abd-El-Khalick, 2017; Ozaskin Arslan ve Ulucinar Sagir, 2020; Yang, Park ve Song, 2020), bilim tarihi (Simpson, Beatty ve Ballen, 2021; Yacoubian, Al-Khatib ve Mardirossian, 2017), görsel temsiller (Akçay ve Akçay, 2018; İnaltekin ve Göksu, 2019; Kapıcı ve Savaşç-Açıalın, 2015; Liu ve Khine, 2016; Qasim ve Pandey, 2017) ve değerlendirme soruları (Aslan, Zor ve Zor, 2019; Çakıcı ve Girgin, 2012) bakımdan analiz edildiği görülmektedir. Bununla birlikte, fen bilimleri konu içeriğini daha anlaşılır hale getirmek için ders kitaplarında tercih edilen örnek 
türlerine odaklanan sistematik bir araştırmanın yapılmadığı da tespit edilmiştir. Dahası, ilgili alan yazında, fen bilimleri alanları içerisinde öğrenciler için her zaman daha karmaşık ve zor gelen fizik konularını öğretmekte kullanılan örnek türlerini irdeleyen bir araştırmaya rastlanmamıştır. Bu araştırma, Türkiye’ de ortaokul 5. sınıflarda okutulan üç adet Fen Bilimleri ders kitabındaki fizik konularını öğretmek için tercih edilen örnek türlerini karşılaştırmaktadır. $\mathrm{Bu}$ kapsamda araştırmanın, ortaokul 5. sınıf Fen Bilimleri derslerinde okutulmak üzere yazılmış kitaplardaki fizik konularını öğretmek için tercih edilen örneklerin ne kadar etkili hazırlandığı ve kitaplarda örnek çeşitliliğinin sağlanıp sağlanmadığına 1 şık tutacağı düşünülmektedir.

\section{Teorik Çerçeve}

\section{Fen bilimlerini öğrenme ve öğretmede kaliteli ders kitapları}

Fen bilimleri karmaşık bir şekilde büyüdükçe, öğrenciler bilimsel bilgileri anlama ve yorumlamada giderek artan zorluklarla yüz yüze kalmaktadırlar (Li ve diğ., 2020). Bu durum öğrencilerin daha etkili fen bilimleri materyalleri ve kaynaklarıyla desteklenmelerini gerektirmektedir (Duschl, Schweingruber ve Shouse, 2007). Fen bilimleri ders kitaplar1, öğrenciler için fen konularının öğrenilmesinde sınıf içi ve dışında en temel kaynaklar olarak kullanılmakta ve bu nedenle derslerde hala oldukça büyük öneme sahiptirler (Nakiboğlu, 2009). Bu kitaplar, öğrencinin oldukça karmaşık fen kavramlarını anlamlandırması ve bilimsel kelime dağarcığının gelişmesine yardımcı olur (Devetak ve Vogrinc, 2013; Mullis, ve diğ., 2012). Binns ve Bell’e (2015) göre Fen Bilimleri kitapları derse ilişkin özel içeriğin detaylı açıklanmasını sağlamaktadır. Kaliteli bir Fen Bilimleri ders kitabının, içeriği ve biçimi bakımından tüm didaktik ilkeleri en verimli şekilde içeren kitap olması gerekir. Ayrıca kaliteli ders kitabının, öğrencilere fen konusunun temel içeriği, yapısı ve sistematiği hakkında net bir fikir vermesi ve böylece rasyonel eğitim sağlamaya yardımcı olması gerekir (Kovac ve Kovac Sebart, 2004). Kaliteli bir Fen Bilimleri ders kitabı için en önemli ölçüt, öğrencilerin gelişim düzeylerini, önceki eğitim seviyelerindeki fen kavramlarıyla ilgili anlayış ve deneyimlerini hesaba katması gerektiği gerçeğidir. Net açıklamalar ve kısa cümlelerle uygun dilin kullanılması önemlidir. Kaliteli Fen Bilimleri ders kitapları için bazı kriterler tanımlanabilir (Tablo 1). Fen ders kitaplarının yazarları bu kriterlerin farkında olmalı ve yeni bir ders kitabı hazırlarken bunları dikkate almalıdır (Devetak ve Vogrinc, 2013). 
Tablo 1. Fen bilimleri ders kitapları için kalite kriterleri

\begin{tabular}{ll}
\hline Kriter & Tanım \\
\hline 1. Yapı açık ve şeffaf olmalıdır. & $\begin{array}{l}\text { Konuların kavramsal gelişimi takip edilerek, içerik mantıksal olarak düzenlenir; ders } \\
\text { kitabındaki öğrenme ünitesinin bir sonucu veya özeti olarak, ünitenin içeriğini } \\
\text { özetleyen bazı aktiviteler sunulur; yazarlar tarafından takip edilen referanslar tutarlı bir } \\
\text { şekilde listelenir. }\end{array}$ \\
$\begin{array}{l}\text { 2. İçerik, öğrenme hedefleri ve } \\
\text { amaçları ile tutarlı olmalıdır. }\end{array}$ & $\begin{array}{l}\text { Öğrenme amaçları ve hedefleri açıkça belirtilir. Ayrıca, öğrencilerin geliştirmeleri } \\
\text { gereken yeterlilikler tanımlanır. Ders kitabı, öğrenme hedeflerine ulaşmaya yardımcı } \\
\text { olur ve öğrencilerin hem genel hem de fen konusuna özgü yeterliliklere ulaşmalarını } \\
\text { sağlar. }\end{array}$ \\
$\begin{array}{l}\text { 3. Tümevarımsal yaklaşım } \\
\text { kullanılmalıdır. }\end{array}$ & $\begin{array}{l}\text { Ders kitaplarının içeriği genelden özele doğru geliştirilir. Her özel bölüm, teorik } \\
\text { bilgininde eklendiği pratik bir problemle başlar. Aynı zamanda teorik bilgi, pratiklerle } \\
\text { birleştirilir. }\end{array}$ \\
$\begin{array}{l}\text { 4. Sunulan bilgi sade ve } \\
\text { doğrulanmış olmalıdır. }\end{array}$ & $\begin{array}{l}\text { Aşrı ayrıtılar, aynı anda bol miktarda yeni bilgi, yeni ve henüz kanıtlanmamış fen } \\
\text { konuları (hızla değişen bilgi ve içerikler) ders kitaplarının bir parçası olmamalıdır. } \\
\text { kenditapları, öğrencileri uygun güncel referanslara yönlendirmeli ve ek bilgileri }\end{array}$ \\
$\begin{array}{l}\text { 5. İçerik didaktik olarak yeterli } \\
\text { olmalıdır. }\end{array}$ & $\begin{array}{l}\text { Ders kitabının içeriği hedef gruptaki öğrencilerin ihtiyaçlarına göre uyarlanmalıdır. } \\
\text { Öğrenme materyali, içeriğin kişiselleştirilmesine ve farklılaşmasına izin vermeli ve } \\
\text { öğrencilerin farklı öğrenme stillerini hesaba katmalıdır. }\end{array}$ \\
\hline
\end{tabular}

Kaliteli eğitimin geliştirilmesinde ders kitapları önemli bir role sahiptir. Eğitim kalitesi ders kitabının kalitesiyle çok yakından ilişkildir (Tikly ve Barrett, 2009). Fen Bilimleri ders kitaplarının, bilgiyi düzenlemeye, sorgulamaya rehberlik etmeye, önemli bilimsel gerçekleri sunmaya, problem çözme becerilerini geliştirmeye, öğrenmeyi pekiştirmeye, soyutlamaları göstermeye ve okuma becerilerini geliştirmeye yardımcı olabileceği bildirilmiştir (Khine ve Liu, 2017; McDonald, 2016). Fen Bilimleri ders kitaplarının, bilimin öğretilme yöntemleri (yani, sorgulamaya dayalı) ve genellikle oluşturulan sınıf öğrenme ortamının türü (öğrenci veya öğretmen merkezli) üzerinde önemli etkileri olduğu da kabul edilmektedir (Valanides, Papageorgiou ve Rigas, 2013). Bir ders kitabının müfredat materyali olarak kullanışl1lığ1, kullanıcıların içeriğini anlayıp anlayamadığına bağlı olarak zayıflayabilir. Ayrıca, potansiyel kullanıcıların seviyelerine uygun olmayan okuma seviyelerine sahip ders kitapları, hayal kırıklığına neden olabilmektedir (Bansiong, 2019). Fen bilimleri ders kitaplarının genç öğrencileri bilime motive etmede önemli payları vardır. Bunlar, genç öğrencileri bilim hakkında etkili bir şekilde bilgi edinmeleri için motive eder. Öğrenciler, ders kitabından hayatı daha iyi anlamak için evren ve toplum hakkında bilgi edinirler (Nabi ve Iqbal, 2018). Dahası öğrencilere, doğal dünyanın nedensel ilişkilerini ve karmaşıklığını tanımlamak için temsiller ve açıklamalar sağlar (Gilbert, 2007).

Fen Bilimleri derslerinde etkili öğrenme sonuçlarının en üst düzeye çıkarılmasına yardımcı olmak için öğrenci ve öğretmenlere yüksek kaliteli ders kitapları temin edilmesi 
hayati önem taşımaktadır (Ball ve Cohen, 1996; Davis ve Krajcik, 2005). Fen Bilimleri ders kitapları, bilimsel bilgiyi eğitim kriterlerine göre yaratıcı bir şekilde detaylandırır ve öğrenciler için yaşa uygun hale getirir. Fen Bilimleri ders kitaplarının etkili olabilmesi için bilimsel bilgileri doğru bir şekilde temsil etmesi gerekir. Kullanıcılar genellikle içeriğin doğruluğunu kesin olarak kabul eder, ancak araştırmalar, birçok yanlış ve hatalı tanım, eski kavram ve terim, yanıltıcı ve eksik ifadeler, eksik bilgiler, bilim adamları tarafından doğrulanmamış fikirler, aşırı basitleştirmeler, aşırı genellemelerin ders kitaplarında var olduğunu göstermektedir (Dikmenli, 2010; Zajkov ve diğ., 2017). Genellikle basitleştirme kisvesi altında, terimlerin tanımlanmasında yeterli özenin olmadığı ve büyük tutarsızlıklar içeren ders kitapların var olduğu vurgulanmaktadır (Bauman, 1992). Eğitim ortamlarında fen öğretimi ders kitabı merkezlidir ve ders kitabında belirtilen hatalar hem öğretmenlerde hem de öğrencilerde yanlış anlamalara neden olabilir (Schizas, Papatheodorou ve Stamou, 2018; Upahi, Ramnarain ve Ishola, 2018). Dolayısısyla kaliteli bir ders kitabının bu hata ve eksikliklerden arındırılmış ve öğrenme hedeflerine ulaşmayı kolaylaştıran bir içeriğe sahip olması gerekmektedir (Akkaya, 2016).

\section{Araştırmanın Amacı ve Problemi}

Fen bilimleri derslerinde nitelikli ders kitaplarının seçilmesi ve kullanılması, öğrenci öğrenme sonuçlarını en üst düzeye çıkarmak için zorunludur. Bu ders kitaplarında sunulan yetersiz bilimsel bilgi, öğrencilerin fikirlerini olumsuz yönde etkileyebilir (Devetak ve Vogrinc, 2013; Irez, 2009). Fen Bilimleri ders kitaplarındaki bilimsel metinlerin etkili sunumu, tercih edilen örnekler, görseller ve aktiviteler ile mümkündür. Bu alandaki birçok bilginin soyut, karmaşık ve zor olduğu düşünüldüğünde, ders kitaplarının bu bilgilerin anlaşılmasını ve hatırlanmasını kolaylaştırıcı örneklerle desteklenmesi gerekmektedir. Özellikle öğrenciler yoğun olarak fizik konularıyla ilköğretim 5. sınıf düzeyindeki Fen Bilimleri dersinde karşılaşmaktadırlar. Bu açıdan bakıldığında bu sınıf düzeyi gelecekteki fizik konularının doğru öğrenilmesinde oldukça önem arz etmektedir. Öğrenciler 5. sınıf düzeyindeki fizik kavramlarını doğru temeller üzerine oturtamazlarsa başarısızlıkları kaçınılmaz olur (Ünsal ve Güneş, 2002). Bu düşünceden hareketle Türkiye’de ortaokul 5. sınıf Fen Bilimleri ders kitaplarının fizik örnek türleri ve bunları ne derece içerdiklerinin tespit edilmesi oldukça önemlidir. Türkiye’de ki Fen Bilimleri ders kitapları üzerine araştırmalar, büyük oranda tercih edilen metinlerin bilimsel doğruluğu, bilimin doğası ve tarihi, görsel içerik, konu etkinlikleri, değerlendirme soruları ve öğretmen görüşlerine göre incelemeleri kapsamaktadır. Buna karşın, Türkiye'de ortaokul 5. sınıf Fen Bilimleri ders kitaplarındaki fizik konularına ilişkin bilimsel 
metinlerin, ne tür örneklerle desteklendiğini inceleyen hiçbir çalışmaya rastlanmamıştır. Bu kapsamda, çalışmada, 2020-2021 eğitim öğretim döneminde Türkiye'deki ortaokul 5. sınıf Fen Bilimleri dersleri için kullanılan kitaplardaki fizik örneklerinin karşılaştırılması amaçlanmıştır. Bu çalışmada ele alınan araştırma soruları aşağıdaki gibidir:

1. 5. sınıf Fen Bilimleri ders kitaplarındaki “kuvvetin ölçülmesi ve sürtünme”, “madde ve değişim”, "1şığın yayılması” ve “elektrik devre elemanları” ünitelerinde hangi tür örnekler kullanılmıştır?

2. Çalışma kapsamında ele alınan kitaplarda, fizik konularının öğretiminde kullanılan örneklerin türü bakımından farklılıklar nelerdir?

\section{Yöntem}

\section{Araştırmanın Deseni}

Bu çalışma, Türkiye'de ortaokullarda okutulmakta olan 5. sınıf Fen Bilimleri ders kitaplarındaki fizik konularının öğretimi için yer alan örnek türlerinin betimlendiği nitel araştırma desenlerinden doküman analizini içermektedir. Nitel araştırmalarda yazılı ve görsel dokümanların incelenmesi zengin ve kapsamlı çıkarımların sağlanması açısından oldukça önemlidir (Bas ve Akturan, 2008). Döküman analizi, basılı ve yazılı tüm belgelerin düzenli ve sistematik bir şekilde analiz edilmesi olarak tanımlanmaktadır (Wach, Ward ve Jacimovic, 2013). Çalışma kapsamında, Talim Terbiye Kurulu Başkanlığg tarafından 2020-2021 eğitim öğretim yılında uygulamaya konulmuş üç adet, 5. sınıf Fen Bilimleri ders kitabı döküman olarak incelenmiştir.

\section{Materyaller}

Türkiye’ deki ortaokullarda fen bilimleri derslerinde okutulucak ders kitapları, "Milli Eğitim Bakanlığı (MEB) Ders Kitapları ve Eğitim Araçları Yönetmeliğı” kapsamında Talim ve Terbiye Kurulu Başkanlığı, örgün ve yaygın eğitim kurumlarında okutulmak amacıyla Türk milli eğitiminin amaç ve temel ilkeler ile öğretim programının amaçladığı kazanımlara uygun olarak hazırlatılmaktadır. Ders kitapları için inceletme yılda iki defa yapılır. Bununla birlikte ders kitaplarının uygunluk süresi, kitabın kabul edildiği öğretim yılından itibaren beş öğretim yılını içermektedir. Uygunluk süresi biten kitaplar için ek süre verilmez. Ayrıca yeniden ders kitabı yazımı gerektirmeyen öğretim programı değişiklikleri bu kitaplara yansıtılır. Bu çalışmanın veri kaynaklarını, 2020-2021 eğitim-öğretim yılında Türkiye'deki ortaokullardaki 5. sınıf Fen Bilimleri derslerinde okutulmak amacıyla özel yayınevi ve MEB tarafından ifade edilen yönetmelikler çerçevesinde hazırlanan üç adet ders kitabı oluşturmuştur. Bu araştırma 
kapsamında incelemeye alınan ortaokul 5. sınıf ders kitaplarının künyeleri Tablo 2'de sunulmuştur.

Tablo 2. Çalışma örneklemine dahil edilen kaynakların künyesi

\begin{tabular}{clc}
\hline Kitap Kodu & \multicolumn{1}{c}{ Ders Kitabının Yazarları } & $\begin{array}{c}\text { Kullanıldığı } \\
\text { Öğretim Türü }\end{array}$ \\
\hline FK1 & $\begin{array}{l}\text { Taş, M., Bozdoğan, A. E. ve Tekbıyık, A. (Ed.). (2019). Ortaokul ve imam } \\
\text { hatip ortaokulu fen bilimleri ders kitabı 5. sinıf. MEB yayınları. }\end{array}$ & Örgün \\
FK2 & $\begin{array}{l}\text { Ünver, E., Yanc1, M. V. ve Arslan, Z. (2019). Ortaokul ve imam hatip } \\
\text { ortaokulu fen bilimleri ders kitabı 5. sinıf. Dikey yayınc1lı. }\end{array}$ & Örgün \\
FK3 & $\begin{array}{l}\text { Civan, B. ve Biltekin, Ö. (2020). Açı öğretim ortaokulu fen bilimleri 5. sinıf. } \\
\text { MEB yayınları. }\end{array}$ & Açık \\
\hline
\end{tabular}

Tablo 2 incelendiğinde, FK1 ve FK2'nin örgün öğretimde, FK3'ün ise aç1k öğretim kurumlarında kullanıldığı görülmektedir. FK3 kodlu ders kitabı, ilköğretim 5. sınıf1 tamamlayamayan ve mecburi ilköğretim 5. sınıf yaş sınırını aşan yetişkinlere, bu sınıf düzeyini tamamlayabilemlerine olanak sağlamak amacıyla hazırlanan ders kaynağını içermektedir.

\section{Verilerin Analizi}

Dökümanların anlaşılması ve çözümlenmesi araştırma için kritik bir aşamadır. Çünkü araştırmacının dökümanın içeriğini yorumlaması gerekmektedir (Baş ve Akturan, 2008; Bowen, 2009). Çalışma kapsamında, ilk olarak ders kitaplarındaki fizik konularını içeren ünitelerindeki örnek türleri kullanım sıklıklarına göre analiz edilmiştir. İkinci olarak ise her üç kitap türü bakımından bu örnek türlerinin karşılaştırmalı analizi yapılmıştır. Bu kapsamda, ders kitaplarındaki fizik konularını içeren üniteler Tablo 3'de sunulmuştur.

Tablo 3. 5. sınıf fen bilimleri ders kitaplarındaki fizik üniteleri ve konular

\begin{tabular}{ll}
\hline Ünite Adı & Konular \\
\hline Kuvvetin Ölçülmesi ve Sürtünme & Kuvvetin Ölçülmesi \\
& Sürtünme Kuvveti \\
\hline \multirow{3}{*}{ Madde ve Değişimi } & Maddenin Hâl Değişimi \\
& Maddenin Ayırt Edici Özellikleri \\
& Isı ve Sıcaklık \\
& Isı Maddeleri Etkiler \\
\hline \multirow{3}{*}{ Işı̆̆ın Yayılması } & Işığın Yayılması \\
& Işığın Yansıması \\
& Işı̆̆ın Maddeyle Karşılaşması \\
& Tam Gölge \\
\hline \multirow{3}{*}{ Elektrik Devre Elemanları } & Devre Elemanlarının Sembollerle Gösterimi ve Devre Şemaları \\
& Basit Bir Elektrik Devresinde Lamba Parlaklığını Etkileyen \\
\hline
\end{tabular}

Tablo 3 incelendiğinde, 5. sınıf Fen Bilimleri ders kitabında "Kuvvetin Ölçülmesi ve Sürtünme, Madde ve Değişim, Işığın Yayılması ve Eketrik Devre Elemanları” olmak üzere 4 
ünitenin yer aldığı görülmektedir. Çalışma kapsamında incelenen ünitelerdeki örnekler için Alkan (2016) tarafından geliştirilen örnek türlerine ait sınıflandırılma sistematiği kullanılmıştır. Literatür incelendiğinde, Alkan (2016)'ın geliştirdiği örnek türlerine ait sınıflandırmanın diğer sınıflandırmalardan daha kapsayıcı ve örnek türlerinin belirlenmesinde daha açıklayıcı bilgiler sunduğundan dolayı çalışmada bu sınıflandırma kullanılmıştır. Alkan (2016)'ın geliştirdiği örnek türlerine ait sınıflandırma sistematiği Tablo 4' te gösterilmiştir.

Tablo 4. Örnek Kategorileri, Kodlar ve Kullanım amaçları (Alkan ve Güven, 2018)

\begin{tabular}{|c|c|c|}
\hline $\begin{array}{l}\text { Örnek } \\
\text { Kategorileri }\end{array}$ & Örneklere Ait Kodlar & Kullanım Amaçları \\
\hline \multirow{3}{*}{$\begin{array}{l}\text { Başlangıç } \\
\text { örnekleri }\end{array}$} & $\begin{array}{l}\text { Konuya öğrencilerin dikkatini } \\
\text { çekme ve hatırlatma (BK1) }\end{array}$ & $\begin{array}{l}\text { Bir konunun başında öğrencilerin konuya ilgisini } \\
\text { çekmek ve öğrencilerinin eski bilgilerini hatırlatmak } \\
\text { amacıyla sunulan örneklerdir. }\end{array}$ \\
\hline & $\begin{array}{l}\text { Tanım için alt yapı oluşturma } \\
\text { (BK2) }\end{array}$ & $\begin{array}{l}\text { Bir konunun başında öğrencilerine konu için } \\
\text { bilmeleri gereken bilgileri içeren örneklerdir. }\end{array}$ \\
\hline & $\begin{array}{l}\text { Konular arası ilişkiyi sağlayarak } \\
\text { konuya giriş yapma (BK3) }\end{array}$ & $\begin{array}{l}\text { Yeni bir konuya başlarken bu konuya eski bir } \\
\text { konuyla bağlantı sağlamak için sunulan örneklerdir. }\end{array}$ \\
\hline \multirow{3}{*}{$\begin{array}{l}\text { Standart } \\
\text { Örnekler }\end{array}$} & Tanımı yansitma (SK1) & $\begin{array}{l}\text { Tanımın ne anlama geldiğini ifade eden prototip } \\
\text { örneklerdir. }\end{array}$ \\
\hline & Kuralı yansitma (SK2) & $\begin{array}{l}\text { Bir kuralın ne anlama geldiğini ifade eden prototip } \\
\text { örneklerdir. }\end{array}$ \\
\hline & $\begin{array}{l}\text { Bir prosedürün nasıl uygulandığını } \\
\text { gösterme (SK3) }\end{array}$ & $\begin{array}{l}\text { Bir işlemsel sürecin basitçe nasıl gerçekleştiğini } \\
\text { ifade eden örneklerdir. }\end{array}$ \\
\hline \multirow{5}{*}{$\begin{array}{l}\text { Geliştirici } \\
\text { Örnekler }\end{array}$} & $\begin{array}{l}\text { Tanımın standart örneklerinin } \\
\text { öğrencilerde oluşan } \\
\text { algıyı genişletmeye çalışma (GK1) }\end{array}$ & $\begin{array}{l}\text { Tanımın standart örneklerinin öğrencilerde oluşan } \\
\text { muhtemel algıyı genişletmeye çalışmak için sunulan } \\
\text { örneklerdir. }\end{array}$ \\
\hline & Kuralı yansitan standart örneklerin & Öğretmenin dersinde bir kuralı ifade ettikten sonra \\
\hline & dişında bu kuralın başka & kuralı yansıtan standart örneklerin dışında bu kuralı \\
\hline & $\begin{array}{l}\text { durumlarla ilişkisini gösterme } \\
\text { (GK2) }\end{array}$ & $\begin{array}{l}\text { başka durumlarla ilişkisini göstermek için sunulan } \\
\text { örneklerdir. }\end{array}$ \\
\hline & $\begin{array}{l}\text { Konular arası ilişkiyi sağlayarak } \\
\text { kavramın sınırlarını genişletme } \\
\text { (GK3) }\end{array}$ & $\begin{array}{l}\text { Konular arası ilişkiyi göstererek öğrencilerde } \\
\text { kavramın sınırlarını genişletmek amacıyla sunulan } \\
\text { örneklerdir. }\end{array}$ \\
\hline Uç Örnekler & $\begin{array}{l}\text { Kavramlara ait istisna durumları } \\
\text { gösterme (UK1) }\end{array}$ & Kavramlara ait istisna durumu içeren örneklerdir. \\
\hline Örnek Diş1 & $\begin{array}{l}\text { Tanıma ait olmayan durumu } \\
\text { gösterme (ÖDK1) }\end{array}$ & $\begin{array}{l}\text { Tanıma ait olamayan durumları ifade etmek için } \\
\text { kullanılan örneklerdir. }\end{array}$ \\
\hline Örnekler & $\begin{array}{l}\text { Kurala ait olmayan durumu } \\
\text { gösterme (ÖDK2) }\end{array}$ & $\begin{array}{l}\text { Kurala ait olmayan durumları ifade etmek için } \\
\text { kullanılan örneklerdir. }\end{array}$ \\
\hline $\begin{array}{l}\text { Karşıt } \\
\text { Örnek }\end{array}$ & $\begin{array}{l}\text { Öğrencilerin yanlış genellemelere } \\
\text { ulaşmalarını engelleme (KK1) }\end{array}$ & $\begin{array}{l}\text { Öğrencilerin yanlış genellemelere ulaşmalarını } \\
\text { engellemek amacıyla kullanılan örneklerdir. }\end{array}$ \\
\hline
\end{tabular}

Tablo 4 incelendiğinde Alkan’ın (2016) örnekleri “Başlangıç, Standart, Geliştirici, Uç, Örnek Dışı ve Karşıt" olmak üzere 6 kategoriye ayırdığı görülmektedir. Aynı zamanda başlangıç, standart ve geliştirici örneklerin 3, örnek dişı örneklerin 2, uç ve karşıt örneklerin tek amaç doğrultusunda kullanıldıkları anlaşılmaktadır.

\section{Çalışmanın Geçerlilik ve Güvenirliliği}

5. sınıf Fen Bilimleri ders kitaplarındaki fizik konularını içeren ünitelerde kullanılan örnekler, alanda uzman iki araştırmacı tarafından Alkan'ın (2016) örnek türleri sınıflandırması 
göz önünde bulundurularak kodlanmış ve kategorilere ayrılmıştır. Çalışmada dokümanların analiz güvenirliği sağlamak amacıyla önce her iki araştırmacıda üç kitabı bağımsız bir şekilde betimlemişlerdir. Daha sonra kodlamanın güvenirliliğini hesaplamak için Miles ve Huberman'ın (1994) önerdiği kodlama güvenirlilik formülü [Görüş Birliği / (Görüş Birliği+Görüş Ayrılığı)] kullanılmıştır. Bu kapsamda çalışmanın kodlaycılar arası tutarlılık yüzdesi 92 olarak tespit edilmiştir. Ayrıca çalışma kapsamında araştırmacılar tarafından betimlenen kodlar ve kategorilerin karşılaştırılması sonrasında farklılık oluşan kod ve kategorilere ait örnekler tekrar incelenmiş ve ortak kategori ve kodlar belirlenmiştir. Örneğin, FK1 kitabındaki madde ve değişim ünitesinde yer alan "maddenin hal ve değişimi” konusuna yönelik kullanılan “Örneğin cam, plastic, demir, çelik gibimaddelerin ısı verilerek kablara dökülmesiyle bardak, çatal, bıçak, kavanoz, oyuncak ve su şişesi gibi pek çok araç gerek elde edilir (Görsel 4.4).” örneği araştırmacılardan biri GK1 olarak kodlarken diğer araştırmacı GK2 olarak kodlamıştır. Daha sonra araştırmacılar bu örneği beraber tekrar incelemiş ve GK1 kodu üzerinde ortak karar vermişlerdir.

\section{Bulgular}

Bu bölümde, MEB’in 2020-2021 y1lı eğitim öğretim döneminde ortaokul 5. sınıflarda Fen Bilimleri derslerinde kullanılması için önerdiği kitaplardaki "Kuvvetin Ölçülmesi ve Sürtünme, Madde ve Değişim, Işı̆̆ın Yayılması ve Elektrik Devre Elemanları” ünitelerinde yeralan örnek türlerinin analiz edilmesi sonucunda elde edilen bulgular sunulmuştur. $\mathrm{Bu}$ kapsamda ilk olarak FK1, FK2 ve FK3 kitaplarındaki ilgili fizik ünitelerinde yeralan örnek türlerine ait frekans değerleri bir bütün olarak Tablo 5’te gösterilmiştir.

Tablo 5. FK1, FK2 ve FK3'deki ilgili ünitelerde yer alan örneklerin sınıflandırılmasına ilişkin frekans değerleri

\begin{tabular}{|c|c|c|c|c|c|c|c|c|c|c|c|c|c|c|c|}
\hline \multirow[b]{3}{*}{ Ünite Adları } & \multirow{3}{*}{ 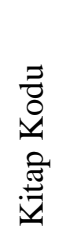 } & \multicolumn{13}{|c|}{ Örnek Türleri } & \multirow{3}{*}{ 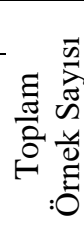 } \\
\hline & & \multicolumn{3}{|c|}{ Başlangıç } & \multicolumn{3}{|c|}{ Standart } & \multicolumn{3}{|c|}{ Geliştirici } & \multirow{2}{*}{ 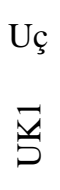 } & \multicolumn{2}{|c|}{ Örnek Diş1 } & \multirow{2}{*}{$\begin{array}{l}\text { Karşı1t } \\
\vec{Z} \\
\vec{Z}\end{array}$} & \\
\hline & & $\frac{\vec{x}}{n}$ & $\frac{\mathscr{x}}{\infty}$ & $\frac{\mathscr{m}}{m}$ & $\frac{\bar{x}}{w}$ & $\frac{\mathfrak{x}}{w}$ & $\frac{n}{\infty}$ & $\frac{\check{Z}}{U}$ & $\frac{\mathbb{x}}{U}$ & $\stackrel{\mathscr{Z}}{\cup}$ & & 尚 & قิ & & \\
\hline \multirow[t]{2}{*}{$\begin{array}{l}\text { 1)Kuvvetin Ölçülmesi } \\
\text { ve Sürtünme }\end{array}$} & FK1 & 8 & 2 & 1 & 34 & 1 & 6 & 15 & 1 & - & - & - & - & - & \multirow[t]{2}{*}{68} \\
\hline & & & 11 & & & 41 & & & 16 & & - & & & - & \\
\hline 2)Madde ve Değişim & FK2 & 13 & 4 & - & 28 & 2 & 7 & 11 & 4 & 2 & - & - & - & - & \multirow[t]{2}{*}{71} \\
\hline 3)Işığın Yayılması & & & 17 & & & 37 & & & 17 & & - & & & - & \\
\hline \multirow{2}{*}{$\begin{array}{l}\text { 4)Elektrik Devre } \\
\text { Elemanları }\end{array}$} & FK3 & 15 & 3 & - & 36 & - & 11 & 6 & 7 & 2 & - & - & - & - & \multirow[t]{2}{*}{80} \\
\hline & & & 18 & & & 47 & & & 15 & & - & & & - & \\
\hline
\end{tabular}


5. sınıf Fen Bilimleri ders kitabındaki "Kuvvetin Ölçülmesi, Madde ve Değişim, Işığın Yayılmas1 ve Elektrik Devre Elemanları" üniteleri incelendiğinde FK1'de 68, FK2'de 71 ve FK3'de 80 örneğin yer aldığı görülmektedir. FK1'deki 68 örneğin 11'inin başlangıç, 41'inin standart ve 16'sının geliştirici, FK2'deki 71 örneğin 17'sinin başlangıç, 37'sinin standart ve 17'sinin geliştirici ve FK3'deki 80 örneğin 18'inin başlangıç, 47'sinin standart ve 15'inin geliştirici örnek türü olduğu tespit edilmiştir. Ayrıca FK1, FK2 ve FK3'deki ilgili ünitelerde, uç, örnek dışı ve karşıt örnek türlerinin kullanılmadığı belirlenmiştir. Çalışma kapsamında incelenen kitaplardaki başlangıç örnek türlerine bakıldığında, FK1'de kullanılan 11 başlangıç örneğinin 8'inin, FK2'de kullanılan 17 örneğin 13'ünün ve FK3'de kullanılan 18 örneğin 15'inin BK1 örnek türünden oluştuğu görülmektedir. Aynı zamanda, FK2 ve FK3'de BK3 türünde örneğin kullanılmadığı da belirlenmiştir. FK1, FK2 ve FK3'deki standart örnek türleri incelendiğinde, FK1'de kullanılan 41 standart örneğin 34'ü SK1, FK2'de kullanılan 37 standart örneğin 28'inin SK1 ve FK3'de kullanılan 47 standart örneğin 36'sının SK1 örnek türünden oluştuğu görülmektedir. Ayrıca, FK3'de SK2 türünde örneğin kullanılmadığı da tespit edilmiştir. Tablo 5 'teki geliştirici örnekler incelendiğinde, FK1'de kullanılan 16 geliştirici örneğin 15'inin GK1, FK2'de kullanılan 17 geliştirici örnek türünden 11'inin GK1 ve FK3'de kullanılan 15 geliştirici örnek türünden 6'sının GK1 ve 7'sinin GK2 örnek türünden oluştuğu belirlenmiş̧tir. Ayn1 zamanda, FK1'de ise GK3 türünde örneğin kullanılmadığı tespit edilmiştir.

FK1, FK2 ve FK3'deki “Kuvvetin Ölçülmesi ve Sürtünme, Madde ve Değişim, Işı̆̆ın Yayılması ve Elektrik Devre Elemanları" ünitelerinde kullanılan örneklerin sınıflandırılmasına ilişkin frekans değerleri sırasıyla tablolar halinde sunulmuştur.

Tablo 6. FK1, FK2 ve FK3'deki "Kuvvetin Ölçülmesi ve Sürtünme” ünitesine yönelik kullanılan örneklerin sinıflandırılması

\begin{tabular}{|c|c|c|c|c|c|c|c|c|c|c|c|c|c|c|c|}
\hline \multirow{3}{*}{ 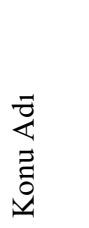 } & \multirow{3}{*}{ 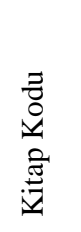 } & \multicolumn{13}{|c|}{ Örnek Türleri } & \multirow{3}{*}{ 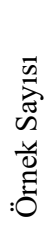 } \\
\hline & & \multicolumn{3}{|c|}{ Başlangıç } & \multicolumn{3}{|c|}{ Standart } & \multicolumn{3}{|c|}{ Geliştirici } & \multirow{2}{*}{ 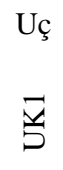 } & \multicolumn{2}{|c|}{ Örnek Dış1 } & \multirow{2}{*}{$\begin{array}{c}\text { Karşıt } \\
\\
\end{array}$} & \\
\hline & & $\stackrel{\vec{v}}{a}$ & $\underset{\sim}{\tilde{a}}$ & $\frac{\mathscr{P}}{n}$ & 离 & $\frac{\widetilde{a}}{\omega}$ & $\stackrel{\mathscr{Z}}{\omega}$ & 胥 & 芯 & 芯 & & $\begin{array}{l}\vec{\theta} \\
: 0\end{array}$ & $\begin{array}{l}\tilde{\hat{\theta}} \\
: 0\end{array}$ & & \\
\hline \multirow{3}{*}{ 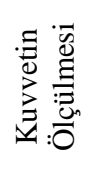 } & FK1 & 2 & 1 & & 1 & & & 1 & & & & & & & 5 \\
\hline & FK2 & 4 & 2 & & 2 & & & 2 & & & & & & & 10 \\
\hline & FK3 & 4 & 1 & & 2 & & & 1 & & & & & & & 8 \\
\hline \multirow{3}{*}{ 害 } & FK1 & & & & 10 & & & 9 & & & & & & & 19 \\
\hline & FK2 & 2 & & & & & & 4 & 3 & & & & & & 9 \\
\hline & FK3 & 1 & & & 7 & & & & 7 & & & & & & 15 \\
\hline
\end{tabular}




\begin{tabular}{llllllllllllllll} 
& FK1 & 2 & 1 & - & 11 & - & - & 10 & - & - & & - & - & - & 24 \\
Toplam & & & 3 & & & 11 & & & 10 & & - & & & \\
Örnek & FK2 & 6 & 2 & - & 4 & - & - & 6 & 3 & - & - & - & - & - & 21 \\
Say1S1 & & & 8 & & & 4 & & & 9 & & \\
& FK3 & 5 & 1 & - & 9 & - & - & 1 & 7 & - & - & - & - & - & 23 \\
\hline
\end{tabular}

Tablo 6’ya bakıldığında kuvvetin ölçülmesi ve sürtünme ünitesi kapsamında toplamda FK1'de 24, FK2'de 21 ve FK3'de 23 örneğin kullanıldığ1 görülmektedir. İlgili ünitede kullanılan başlangıç türü örnekler incelendiğinde, FK2 ve FK3'de kullanılan başlangıç örneklerinin genellikle BK1 türü örnekler olduğu, FK1'deki örneklerin ise 2'sinin BK1, 1'inin BK2 türü örnekler oldukları tespit edilmiştir. Standart türü örneklere bakıldığında, üç kitapta da kullanılan örneklerin tamamının SK1 türü örnekler olduğu belirlenmiştir. Geliştirici örnek türleri incelendiğinde ise, genellikle FK1 ve FK2'de kullanılan örneklerin GK1 türü örnekler, FK3'de kullanılan örneklerin ise GK2 türü örnek olduğu tespit edilmiştir. Ayrıca ilgili ünite kapsamında, bu üç kitapta da BK3, SK2, SK3 ve GK3 türünde örneklerin kullanılmadığ1 belirlenmiştir. Kuvvetin ölçülmesi konusunda kullanılan başlangıç türü örnekler incelendiğinde, FK2 ve FK3’deki örneklerin çoğunun BK1 türünden örneklerden oluştuğu, BK3 türünden örneklere ise yer verilmediği görülmektedir. Standart ve geliştirici örnek türlerine bakıldığında ise kitaplarda sadece SK1 ve GK1 türünden örneklerin kullanıldığ1 belirlenmiştir. Her üç kitapta da kullanılan başlangıç örnek türlerine ilişkin alıntı örnekleri tablo 7’de sunulmuştur.

Tablo 7. Ders kitaplarında kullanılan başlangıç örneklerinden alıntılar

\begin{tabular}{lcc}
\hline Kitap & Örnek & Örnek \\
Kodu & türü &
\end{tabular}

Bir bebek arabasını itmek kolayken bir otomobili itmek zordur. (s.81)
Insanlar tarlaları ekip biçmede, eşyalarının yerini değiştirmede, yük taşımada, yemek yapmada,
duvvar boyamada kisaca bir çok faaliyette kuvvet uygular ve uygulamaya devam edecektir. (s.62)
etkisinden yararlanmaktadır (s.61-62). 
Tablo 6'daki “sürtünme kuvveti” konusuda kullanılan başlangıç türü örnekleri incelendiğinde, FK1'de bu örnek türüne yer verilmediği, FK2'de 2 BK1, FK3'de ise 1 BK1 türünde örnek kullanıldığı görülmüsstür. $\mathrm{Bu}$ konuda kullanılan standart türü örnekler incelendiğinde, FK1'de 10 FK3'de 7 SK1 türünden örneklerin kullanıldığ1 fakat FK2'de bu örnek türüne yer verilmediği belirlenmiştir. Geliştirici türden örnekler incelendiğinde ise FK1'de 9 GK1 türünden örneğin, FK2'de 4 GK1 ve 3 GK2 türünde örneğin ve FK3'de ise 7 GK2 türünden örneğin kullanıldığı görülmüştür.

Tablo 8. FK1, FK2 ve FK3' deki “Madde ve Değişim” ünitesine yönelik kullanılan örneklerin siniflandirilmasi

\begin{tabular}{|c|c|c|c|c|c|c|c|c|c|c|c|c|c|c|c|}
\hline \multirow{3}{*}{ 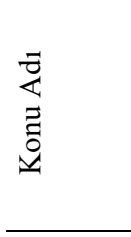 } & \multirow{3}{*}{ 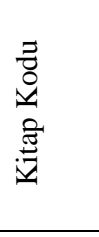 } & \multicolumn{13}{|c|}{ Örnek Türleri } & \multirow{3}{*}{ 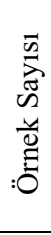 } \\
\hline & & \multicolumn{3}{|c|}{ Başlangıç } & \multicolumn{3}{|c|}{ Standart } & \multicolumn{3}{|c|}{ Geliştirici } & \multirow{2}{*}{$\begin{array}{l}\text { Uç } \\
\ddot{z} \\
\vec{b}\end{array}$} & \multicolumn{2}{|c|}{ Örnek D1ş1 } & \multirow{2}{*}{$\begin{array}{c}\text { Karşı1t } \\
\underset{z}{z}\end{array}$} & \\
\hline & & $\frac{\vec{x}}{n}$ & $\frac{\widetilde{x}}{\mathscr{n}}$ & $\frac{\mathscr{n}}{n}$ & $\vec{v}$ & 艾 & $\begin{array}{l}\mathscr{n} \\
\text { v }\end{array}$ & 胥 & $\frac{\mathscr{V}}{0}$ & 胥 & & 常 & $\begin{array}{l}\tilde{\text { Aี }} \\
: 0\end{array}$ & & \\
\hline \multirow{3}{*}{ 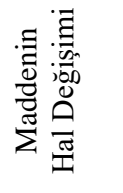 } & FK1 & & & & 8 & & 3 & 2 & 1 & & & & & & 14 \\
\hline & FK2 & 2 & & & 9 & & 5 & 2 & & & & & & & 18 \\
\hline & FK3 & 1 & & & 10 & & 2 & 1 & & 1 & & & & & 15 \\
\hline \multirow{3}{*}{ 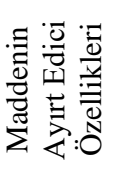 } & FK1 & 1 & & & 2 & & & & & & & & & & 3 \\
\hline & FK2 & 1 & & & 2 & & & & & 1 & & & & & 4 \\
\hline & FK3 & 2 & & & 4 & & 2 & & & & & & & & 8 \\
\hline \multirow{3}{*}{ 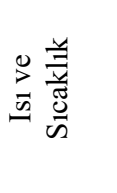 } & FK1 & 1 & & & 2 & & 1 & & & & & & & & 4 \\
\hline & FK2 & 1 & 2 & & 1 & & & & 1 & 1 & & & & & 6 \\
\hline & FK3 & 2 & & & 2 & & 1 & & & & & & & & 5 \\
\hline \multirow{3}{*}{ 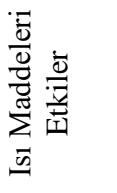 } & FK1 & & & & 4 & & 2 & 2 & & & & & & & 8 \\
\hline & FK2 & 1 & & & 3 & & 2 & 2 & & & & & & & 8 \\
\hline & FK3 & & & & 2 & & 5 & 2 & & & & & & & 9 \\
\hline \multirow{6}{*}{ 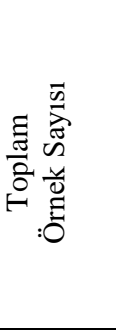 } & & 2 & - & - & 16 & - & 6 & 4 & 1 & - & & & & & \\
\hline & FKI & & 2 & & & 22 & & & 5 & & - & - & - & - & 29 \\
\hline & & 5 & 2 & - & 16 & - & 7 & 4 & 1 & 2 & & & & & \\
\hline & FK $\angle$ & & 7 & & & 23 & & & 7 & & - & - & - & - & 37 \\
\hline & FK3 & 5 & - & - & 18 & - & 10 & 3 & - & 1 & - & - & - & - & 37 \\
\hline & & & 5 & & & 28 & & & 4 & & & & & & \\
\hline
\end{tabular}

Tablo 8'e bakıldığında “madde ve değişim” ünitesi kapsamında toplamda FK1'de 29, FK2'de 37 ve FK3'de 37 örneğin kullanıldığı görülmektedir. İlgili ünitede kullanılan başlangıç türü örnekler incelendiğinde, FK1 ve FK3'de kullanılan başlangıç türü örneklerinin tamamı, FK2'de kullanılan örneklerin ise çoğunluğunun BK1 türü örneklerden oluştuğu belirlenmiştir. 
Standart türü örnekler incelendiğinde, üç kitapta da kullanılan örneklerin SK1 ve SK3 türü örneklerden oluştuğu tespit edilmiştir. 5. sınıf Fen Bilimleri kitaplarındaki geliştirici örnek türleri incelendiğinde ise, kitaplardaki örneklerin genellikle GK1 türü örneklerden seçildiği görülmektedir. Ayrıca üç kitapta da BK3 ve SK2 türü örneklerin kullanılmadığı tespit edilmiştir. “Madde ve Değişim” ünitesi, madenin hal değişimi, maddenin ayırt edici özelliklei, 1S1 ve sıcaklık ve 1Sı maddeleri etkiler konularından oluşmaktadır. "Maddenin hal değişimi”" konusundaki başlangıç örnekleri incelediğinde, FK2 ve FK3'de BK1 türünde örneklerin kullanıldığı, FK1'de başlangıç örneklerine yer verilmediği görülmektedir. İlgili konuda kullanılan standart türü örnekler incelendiğinde, üç kitapta da SK1 ve SK3 türündeki örneklerin kullanıldığı, SK2 türündeki örneklerin ise kullanılmadığı belirlenmiştir. Ayrıca geliştirici örnek türleri incelendiğinde, FK1'de 2 GK1 ve 1 GK2 türünde örneğin, FK2'de sadece 2 GK1 türünde örneğin, FK3'de ise 1 GK1 ve 1 GK3 türü örneğin kullanıldığı tespit edilmiştir. Her üç kitapta da kullanılan standart örnek türlerine ilişkin örnek alıntılar Tablo 9’da, sunulmuştur.

Tablo 9. Ders kitaplarında kullanılan geliştirici örneklerinden alıntılar

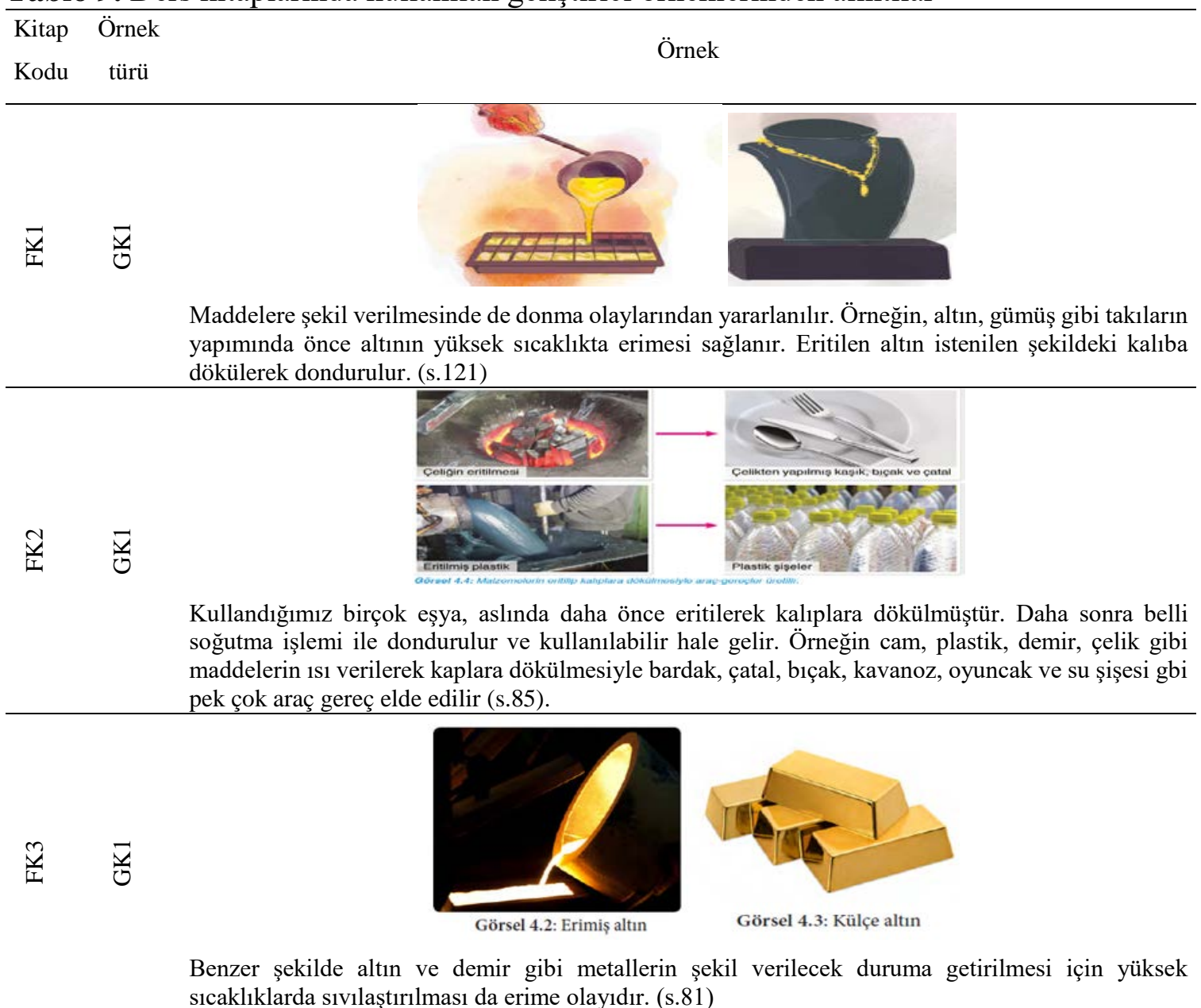


Tablo 8'deki "maddenin ayırt edici özellikleri” konusunda kullanılan başlangı̨̧ örnekleri incelediğnde, üç kitapta da kullanılan örneklerin tamamının BK1 türü örnek olduğu görülmektedir. Standart örnek türleri incelendiğinde, FK1 ve FK2'de kullanılan örneklerin tamamının, FK3'de kullanılan 6 örneğin 4'ünün SK1 türü örnek olduğu tespit edilmiştir. Geliştirici örneklere bakıldığında ise, FK1 ve FK3'de bu örnek türlerinin kullanılmadığı, FK1'de yalnızca 1 GK3 örnek türüne yer verildiği görülmektedir. Her üç kitapta da kullanılan standart örnek türlerine ilişkin örnek alıntılar Tablo 10'da sunulmuştur.

Tablo 10. Ders kitaplarında kullanılan standart örneklerinden alıntılar

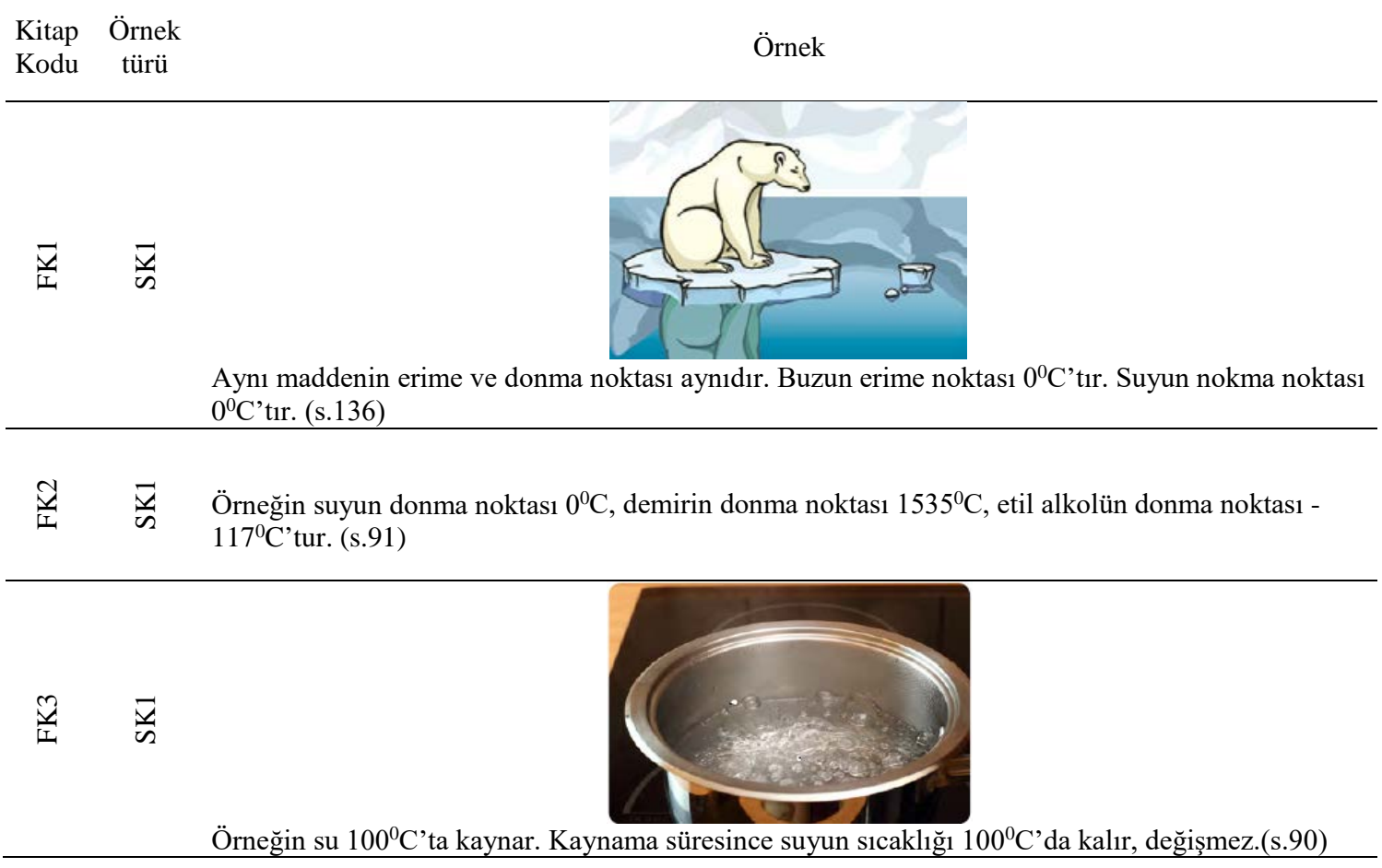

“Is1 ve sıcaklık” konusuda kullanılan başlangıç örnek türleri incelendiğinde, FK1 ve FK3'de sadece BK1 türü örneğin kullanıldığ1, FK2'de ise 1 BK1 ve 2 BK2 türü örneğin kullanıldığı görülmektedir. İlgili konu kapsamında standart türü örneklere baktığımızda, üç kitapta da genellikle SK1 türünde örneklere yer verildiği belirlenmiştir. Geliştirici türde örnekler incelendiğinde ise, sedece FK2 de bu örnek türüne yer verildiği, FK1 ve FK3 de bu örnek türüne yer verilmediği tespit edilmiştir.

"Isı maddeleri etkiler” konusunda kullanılan başlangıç örnekleri incelendiğinde, FK1 ve FK3'de bu tür örneklerin kullanılmadığ1, sadece FK2'de 1 BK1 türü örneğin kullanıldığ tespit edilmiştir. Standart örnek türlerine bakıldığında, üç kitapta da SK1 ve SK3 türünde örneklerin kullanıldığg fakat SK2 türünde örneklerin kullanılmadığg belirlenmiştir. Geliştirici 
örnekler incelendiğinde ise, kitaplarda sadece GK1 türünde örneklere yer verildiği görülmüştür.

Tablo 11. FK1, FK2 ve FK3'deki “Ișığın Yayılması” ünitesine yönelik kullanılan örneklerin siniflandirilması

\begin{tabular}{|c|c|c|c|c|c|c|c|c|c|c|c|c|c|c|c|}
\hline \multirow{3}{*}{ 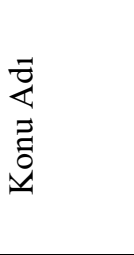 } & \multirow{3}{*}{ 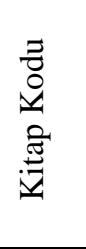 } & \multicolumn{13}{|c|}{ Örnek Türleri } & \multirow{3}{*}{ 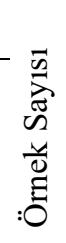 } \\
\hline & & \multicolumn{3}{|c|}{ Başlangıç } & \multicolumn{3}{|c|}{ Standart } & \multicolumn{3}{|c|}{ Geliştirici } & \multirow{2}{*}{ 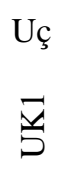 } & \multicolumn{2}{|c|}{ Örnek D1şı } & \multirow{2}{*}{ 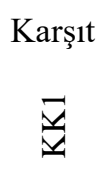 } & \\
\hline & & $\frac{\vec{x}}{D}$ & $\frac{\mathscr{v}}{\infty}$ & $\frac{n}{n}$ & $\frac{\vec{x}}{w}$ & $\frac{\tilde{T}}{\infty}$ & $\frac{n}{\infty}$ & ت্ডে & $\underset{\mathcal{Z}}{\mathcal{U}}$ & $\frac{n}{0}$ & & $\begin{array}{l}\vec{\theta} \\
: 0\end{array}$ & $\begin{array}{l}\tilde{\theta} \\
: 0\end{array}$ & & \\
\hline \multirow{3}{*}{ 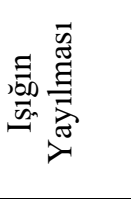 } & FK1 & & & & 1 & & & & & & & & & & 1 \\
\hline & FK2 & & & & 1 & 2 & & & & & & & & & 3 \\
\hline & FK3 & 1 & 2 & & 3 & & & & & & & & & & 6 \\
\hline \multirow{3}{*}{ 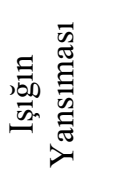 } & FK1 & 1 & 1 & & 3 & & & & & & & & & & 5 \\
\hline & FK2 & & & & 3 & & & & & & & & & & 3 \\
\hline & FK3 & 2 & & & 2 & & & & & & & & & & 4 \\
\hline \multirow{3}{*}{ 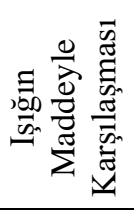 } & FK1 & 1 & & & 3 & 1 & & & & & & & & & 5 \\
\hline & FK2 & 1 & & & 3 & & & & & & & & & & 4 \\
\hline & FK3 & & & & 3 & & 1 & 2 & & & & & & & 6 \\
\hline \multirow{3}{*}{ 苂 } & FK1 & & & 1 & & & & & & & & & & & 1 \\
\hline & FK2 & 1 & & & 1 & & & & & & & & & & 2 \\
\hline & FK3 & 1 & & & 1 & & & & & 1 & & & & & 3 \\
\hline \multirow{4}{*}{ 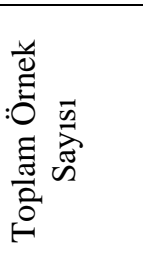 } & БK 1 & 2 & 1 & 1 & 7 & 1 & - & - & - & - & 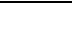 & 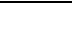 & 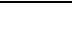 & 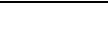 & 12 \\
\hline & FNI & & 4 & & & 8 & & & - & & - & - & - & - & 12 \\
\hline & FK2 & 2 & - & - & 8 & $\begin{array}{l}2 \\
10\end{array}$ & - & - & - & - & - & - & - & - & 12 \\
\hline & FK3 & 4 & $\begin{array}{l}2 \\
6\end{array}$ & - & 9 & $\begin{array}{l}- \\
10\end{array}$ & 1 & 2 & -3 & 1 & - & - & - & - & 19 \\
\hline
\end{tabular}

Tablo 11’e bakıldığında “1şı̆̆ın yayılması” ünitesi kapsamında toplamda FK1'de 12, FK2'de 12 ve FK3'de 19 örneğin kullanıldığı görülmektedir. İlgili ünitede kullanılan başlangıç türü örnekler incelendiğinde, kitaplarda genellikle BK1 türü örneğin kullanıldığı görülmektedir. Ayrıca BK3 türü örneğin sadece FK1'de kullanıldığı tespit edilmiştir. Standart türü örnekler incelendiğinde, genellikle bu üç kitapta da SK1 türü örneklere yer verildiği tespit edilmiştir. Ayrıca tabloda geliştirici örneklere bakıldığında, sadece FK3 kitabında bu örnek türlerinin kullanıldığı belirlenmiştir. “Işığın yayılması” konusunda kullanılan başlangıç örnekleri incelediğnde, FK1 ve FK2'de bu örnek türlerine yer verilmediği, FK3'de ise 1 BK1 ve 2 BK2 türü örnek olmak üzere 3 başlangıç örneğine yer verildiği tespit edilmiştir. Standart örnek türlerine bakıldığında, FK1 ve FK3'de sadece SK1 türünde örneklerin kullanıldığg, 
FK2'de ise hem SK1 hem de SK2 türünde örneklerin kullanıldığ1 görülmektedir. Ayrıca geliştirici örnek türlerine bakıldığında, üç kitapta da bu tür örneklerin kullanılmadığı tespit edilmiştir. “Işığın yanısıması” konusuda kullanılan başlangıç örnekleri incelendiğinde, FK2'de bu türde örnek kullanılmadığı, FK1 ve FK3'de başlangıç türü örneklerinin kullanıldığı tespit edilmiştir. Standart türü örneklere bakıldığında, üç kitaptada kullanılan örneklerin tamamının SK1 türünde örnekler oldukları belirlenmiştir. Ayrıca Tablo 11'e bakıldığında, kitaplarda geliştirici örneklere yer verilmediği de görülmektedir. "Işı̆̆̆ı madde ile karşılaşması" konusunda kullanılan başlangıç örnekleri incelediğnde, FK3'de bu türde örnek kullanılmadığg, FK1 ve FK2'de 1'er BK1 türü örneğin kullanıldığ1 tespit edilmiştir. Standart türü örneklere bakıldığında, kitaplarda genellikle SK1 türü örneğin kullanıldığ1 görülmektedir. Geliştirici türdeki örnekler incelendiğinde ise, FK3'de GK1 türü örneklerin kullanıldığg, FK1 ve FK2'de bu örnek türlerine yer verilmediği belirlenmiştir. “Tam gölge” konusuda kullanılan başlangıç örnekleri incelendiğinde, FK1'de BK3 türü örneğinin, FK2 ve FK3'de BK1 türü örneğinin kullanıldığg tesit edilmiştir. Standart türü örnekler incelendiğinde, FK1'de bu türde örneklerin yer almadığı, FK2 ve FK3'de 1'er SK1 türü örneğinin kullanıldığı belirlenmiştir.

Tablo 12. FK1, FK2 ve FK3'deki "Elektrik Devre Elemanları" ünitesine yönelik kullanılan örneklerin sınıflandırılması

\begin{tabular}{|c|c|c|c|c|c|c|c|c|c|c|c|c|c|c|c|}
\hline \multirow{3}{*}{$\begin{array}{l}\vec{z} \\
\vdots \\
\vec{\Xi} \\
\qquad\end{array}$} & \multirow{3}{*}{ 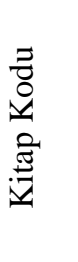 } & \multicolumn{13}{|c|}{ Örnek Türleri } & \multirow{3}{*}{ 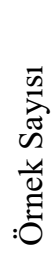 } \\
\hline & & \multicolumn{3}{|c|}{ Başlangıç } & \multicolumn{3}{|c|}{ Standart } & \multicolumn{3}{|c|}{ Geliştirici } & \multirow{2}{*}{ 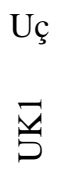 } & \multicolumn{2}{|c|}{ Örnek Dış1 } & \multirow{2}{*}{$\begin{array}{c}\text { Karşıt } \\
\vec{z}\end{array}$} & \\
\hline & & $\vec{z}$ & ָัָ & $\stackrel{\mathscr{m}}{\infty}$ & $\vec{x}$ & జี & $\underset{n}{n}$ & 晃 & 胥 & 胥 & & $\begin{array}{l}\vec{\theta} \\
: 0\end{array}$ & $\begin{array}{l}\tilde{\hat{\theta}} \\
0\end{array}$ & & \\
\hline \multirow{3}{*}{ 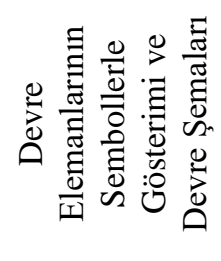 } & FK1 & 2 & & & & & & 1 & & & & & & & 3 \\
\hline & FK2 & & & & & & & 1 & & & & & & & 1 \\
\hline & FK3 & 1 & & & & & & & & & & & & & 1 \\
\hline \multirow{3}{*}{ 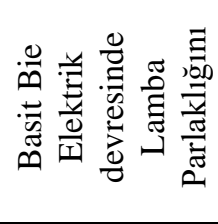 } & FK1 & & & & & & & & & & & & & & \\
\hline & FK2 & & & & & & & & & & & & & & \\
\hline & FK3 & & & & & & & & & & & & & & \\
\hline \multirow{3}{*}{$\begin{array}{l}\text { Toplam } \\
\text { Örnek Sayısı }\end{array}$} & FK1 & 2 & & & & & & 1 & & & & & & & 3 \\
\hline & FK2 & & & & & & & 1 & & & & & & & 1 \\
\hline & FK3 & 1 & & & & & & & & & & & & & 1 \\
\hline
\end{tabular}


Tablo 12'ye bakıldığında “elektrik devre elemanları” ünitesi kapsamında toplamda FK1'de 3, FK2 ve FK3'de birer örneğin kullanıldığg görülmektedir. İlgili ünite kapsamında üç kitapta da sadece “devre elemanlarının sembollerle gösterimi ve devre şemaları” konusuna yönelik örneklerin kullanıldığı tespit edilmiştir. FK1'de kullanılan örneklerin başlangıç ve geliştirici örnekler olduğu, FK2'de kullanılan örneğin geliştirici, FK3'de kullanılan örneğin ise başlangıç örneği olduğu belirlenmiştir. Ayrıca, kitaplarda standart türü örneklerin kullanılmadı̆̆ı da tespit edilmiştir.

\section{Tartışma ve Sonuç}

Bu çalışmada, 2020-2021 eğitim-öğretim döneminde Türkiye'de ortaokul 5. sınıf Fen Bilimleri derslerinde okutulan üç adet ders kitabı, fizik konularının öğretimi için tercih edilen örnekler bakımından karşılaştırılmıştır. Araştırma sonucunda, Türkiye'de 5. sınıf Fen Bilimleri dersi kitaplarında fizik konularının öğretimi için tercih edilen örnek türlerinin her üç kitaptada ele alınan fizik konuları bakımından büyük oranda standart örneklerden oluştuğu görülmüştür. Başlangıç ve geliştirici örnek türlerinin ise tüm fizik konularının öğretimde çok daha az sayılarda tercih edildiği belirlenmiştir. Buna karşın uç örnekler, örnek dışı örnekler ve karşıt örneklere ise, kitapların üçünde de fizik konularının öğretimi için yer verilmediği saptanmıştır. Ayrıca her üç kitapta da standart örnek türleri bakımından, prototip örneklerin büyük oranda tercih edildiği görülmüştür. Her üç kitap türü bakımından kıyaslama yapıldığında, ifade edilen sonuçların, diğer iki kitaba göre FK3 (Açık Öğretim) kodlu kitapta daha fazla öne çıktığı anlaşılmıştır. Fizik konularının öğretimine yönelik tercih edilen örnekler incelendiğinde fen bilimleri ders kitaplarının her birinde farklılıklar göze çarpmaktadır. Fizik konularının öğretimindeki örnek temsiline ilişkin bu farklılıklar, kitap yazarlarının kendi görüşleri ve ilgisine atfedilebilir.

Araştırma kapsamında ele alınan her üç kitapta da "Kuvvetin Ölçülmesi ve Sürtünme” ünitesindeki konuların öğretimi için yaklaşık aynı sayıda örnek kullanıldığı görülmüştür. Ayrıca, bu ünitedeki örneklerin, başlangıç, standart ve geliştirici örnek türlerini içerdiği anlaşılmıştır. Kullanılan örnek türlerine bakıldığında ise bu üç kitapdan, FK1'de başlangıç türü örneklerin, FK2'de ise standart örneklerin daha az sayıda kullanıldığı belirlenmiştir. Bu sonuçlar göz önüne alındığında, bu ünite kapsamında tercih edilen başlangıç, standart ve geliştirici örnek türlerinin yanında karşıt örneklerinin kullanılmasının, öğrencilerin yanlış öğrenmelerini engellemede etkili olacağ1 söylenebilir. Çünkü öğrenciler bu konuda birçok yanlış öğrenmelere sahip olabilmektedirler. İlgili alan yazına göre fizik konularının 
öğretiminde öğrencilerin, kuvvet ve sürütünme konusunda fazlaca alternatif kavramlara sahip olduğu görülmektedir (Nie, Xiao, Fritchman, Liu, Han, Xiong ve Bao, 2019; Sari, Ramdhani ve Surtikanti, 2019). Güneş ve diğerleri (2017) kuvvet ve sürtünme konusu üzerine kapsamlı çalışmalarında, öğrencilerin mevcut yanlış öğrenmeleri üzerinde durmuşlardır. $\mathrm{Bu}$ çalışmalarında kuvvet kavramını, "Cisimler arasındaki itme ve çekme şeklindeki etkileşimdir." olarak tanımlamışlardır. Bu tanımlamaların, öğrencilerin konuya ilişkin yanlış genellemeler yapabilmelerıne yol açabileceğinden dolayı, hem karşıt hemde örnek dışı örneklerle ders kitaplarının zenginleşitirlmesi gerekmektedir. Çünkü bu örnek türlerinin, kuvvet ve sürtünme konusuna ilişkin tanımlara ait olmayan durumları açıklayabilmede daha etkili olacağı söylenebilir.

“Madde ve Değişimi” ünitesi kapsamında ders kitaplarında kullanılan örneklerin incelenmesi sonucunda, FK2 ve FK3' de kullanılan toplam örnek sayısının FK1'e kıyasla daha fazla olduğu görülmüştür. Bu üç kitapta kullanılan örneklerin genellikle başlangıç, standart ve geliştirici örnek türlerinin olduğu ve daha çok standart örnek türlerine yer verildiği anlaşılmıştır. Bu durum öğrencilerin ilgili ünite kapsamındaki tanımları ifade edebilmelerinde olumlu katkıları olmasına rağmen, tanımları zihinlerinde yapılandırmada ve yanlış genellemeler yapmalarının önüne geçmede yetersiz kaldığg söylenebilir. Bu kapsamda "Madde ve Değişimi” konusunda sunulan birçok karmaşık bilginin öğrenciler tarafından anlaşılmasını kolaylaştırmak için bilimsel metinlerin uç, örnek dışı ve karşıt örneklerle bütünleştirilmesi gereklidir. Çünkü bilimsel metinlere, uygun şekilde hazılanmış örneklerin eklenmesi, öğrencilerin bilgileri daha kolay ilişkilendirme, anlama ve hatırlayabilmelerine katkı sağlayacaktır (Rohmah, Fariati ve Ibnu, 2020). Ayrıca bu üç kitaptan, FK1'de başlangıç türü örneklere daha az yer verildiği tespit edilmiştir. Çoğu zaman "Madde ve Değişimi" ünitesindeki bilgilerin yoğunluğu ve karmaşıklığından dolayı öğrencilerin dikkati ve motivasyonlarının azalması kaçınılmaz olabilmektedir. Bu durum ortaokul öğrencileri için fen bilimleri ders kitaplarındaki "Madde ve Değişimi” konusuna ilişkin, bilgi içeriğinin anlaşılmasını kolaylaştıran örneklerin sayısı ve çeşitliliğinin artırılmasıyla giderilebilir.

"Işı̆̆ın Yayılması" ünitesi kapsamında ders kitaplarında kullanılan örneklerin incelenmesi sonucunda, FK3'te kullanılan toplam örnek sayısının FK1 ve FK2'ye kıyasla daha fazla olduğu görülmüştür. İlgili ünitedeki konuların yoğun şekilde soyut kavramları içermesinden dolayı, öğrencilerin bu kavramları anlamlandırabilmelerini ve mutemel algılarını genişletebilmelerine imkân tanıyacak zengin örneklerle desteklenmesi gerekmektedir (Widiyatmoko ve Shimizu, 2018). Ayrıca FK1 ve FK2'de sadece başlangıç ve standart örnek 
türlerine yer verilirken, FK3' de geliştirici örnek türününde kullanıldığı anlaşılmıştır. Bu ünite kapsamında kullanılan örneklerin çoğunlukla standart örnek türleri olduğu sonucuna varılmıştır. "Işı̆̆ın Yayılması" ünitesi kapsamında kullanılan standart örnek türlerinin, daha çok öğrencilerin tanımları ifade edebilmelerine yardımcı olduğu fakat bu tanımlara ilişkin algılarını genişletmekte yetersiz kaldığı ifade edilebilir. Bu durumu gidermek için ilgili ünite kapsamında geliştirici örnek türlerinin kullanılması son derec önem arz etmektedir.

“Elektrik Devre Elemanları” ünitesi kapsamında ders kitaplarında kullanılan örneklerin incelenmesi sonucunda, her üç kitapta da örnek kullanımının çok sınırlı sayıda olduğu görülmüştür. Ayrıca bu kitaplardan FK1'de daha fazla örnek ve örnek türünün kullanıldığı anlaşılmıştır. Bununla birlikte, fizik konularını içeren üniteler içerisinde "Elektrik Devre Elemanları" ünitesinin diğer ünitelere kıyasla oldukça az sayıda örnek ve örnek türünü içerdiği saptanmıştır. Bu sonuçlar dikkate alındığında ders kitaplarında "Elektrik Devre Elemanları" konularının öğretiminde tercih edilen örnekler bakımından zenginleştirilmeye ihtiyaç duyduğu anlaşılmaktadır. Dolayısıyla ilgili konu metnine daha farklı örnek temsillerin dahil edilmesinin, bilişsel ve duyuşsal alanlarda öğrenci performansını arttıracağı söylenebilir (Lin, 2016; Moodley ve Gaigher, 2019). Aynı zamanda ders kitabı yazarlarının, öğrencilerin "Elektrik Devre Elemanları" ünitesindeki konuları daha kolay öğrenmeye teşvik etmek için bu konuları daha farklı örnek türleriyle nasıl bağlayacakları konusunda sınırlı kaldıkları görülmektedir. Bu bağlamda, ders kitaplarındaki “Elektrik Devre Elemanları” konularını öğretirken daha nitelikli örnekler üzerinden vurguların yapılabilmesi, öğrencilerin konuya ilişkin kavramları daha derinlemesine anlamalarına yardımcı olabilir.

\section{Öneriler}

$\mathrm{Bu}$ araştırmanın sonuçları doğrultusunda yeni araştırmalar ve fen bilimleri ders kitabı hazırlayacaklara şu öneriler sunulabilir: Öğretmen ve öğrencilerle örnekler üzerine yapılacak görüşmeler bu ders kitaplarının iyileştirilmesine ve zenginleştirilmesine katkı sağlayacaktır. Bir diğer öneri olarak, fen bilimleri eğitiminde başarılı ülkelerin ders kitaplarındaki fizik konuları için tercih edilen örnekler üzerine incelemeler ve karşılaştırmalar yapılmalıdır. Yine ders kitapları hazırlanırken bilimsel metinlerin dışında sadece kullanılacak örnekler üzerine çalışacak uzmanlar ve fen bilimleri öğretmenlerinden oluşan ayrı bir komsiyon kurulabilmelidir. Bu çalışmanın sonuçlarının, bu alandaki gelecekteki araştırmalar için olduğu kadar ders kitaplarının yazarları için de bazı çıkarımları vardır. Fen bilimleri ders kitaplarının 
yazarlarının örnek kullanımına ilişkin akademi dünyasından en son görüşleri dikkate almaları ve bu bilgileri fen ders kitaplarına hızlı bir şekilde yansıtabilmelidirler.

\section{Makalenin Bilimdeki Konumu}

Matematik ve Fen Bilimleri Eğitimi Bölümü/Fen Bilgisi Eğitimi

\section{Makalenin Bilimdeki Özgünlüğü}

Literatürde fen bilimleri ders kitapları üzerine yer alan çalışmların büyük kısmının, konu etkinlikleri, bilimin doğası, görsel temsiller ve değerlendirme sorularını içerdiği anlaşılmaktadır. Bununla birlikte fen bilimleri konu içeriğini daha anlaşılır hale getirmek için ders kitaplarında tercih edilen örnek türlerine odaklanan sistematik bir araştırmanın yapılmadığı da tespit edilmiştir. Dahası, ilgili alan yazında, fen bilimleri alanları içerisinde öğrenciler için her zaman daha karmaşık ve zor gelen fizik konularını öğretmekte kullanılan örnek türlerini irdeleyen bir araştırmaya rastlanmamıştır. Bu nedenle, ortaokul 5. sınıf fen bilimleri derslerinde okutulmak üzere yazılmış kitaplardaki fizik konularını öğretmek için tercih edilen örneklerin ne kadar etkili hazırlandığı ve kitaplarda örnek çeşitliliğinin sağlanıp sağlanmadığı incelemeye alınmıştır.

\section{Kaynakça}

Abd-El-Khalick, F. (2002). Images of nature of science in middle grade science trade books. The New Advocate, 15(2), 121-127.

Abd-El-Khalick, F., Belarmino, J., Brunner, J., Le, A.-P., Myers, J. Y., Summers, R.G., et. al. (2017). A longitudinal analysis of the extent and manner of representations of nature of science in U.S. high school chemistry, biology, and physics textbooks. In C. V. McDonald \& F. Abd-El-Khalick (Eds.), Representations of nature of science in school science textbooks: A global perspective (pp. 20-60). London: Routledge. 
Ahtineva, A. (2005). Textbook analysis in the service of chemistry teaching. Universitas Scientiarum, 10, 25-33.

Akçay, B., \& Akçay, H. (2018). Descriptive analysis of diagrammatic representations of Turkish middle school science textbooks. The Eurasia Proceedings of Educational \& Social Sciences (EPESS), 9, 193-199.

Akçay, B., Akçay H., ve Kahramanoğlu E. (2017). Ortaokul fen bilimleri ders kitaplarının bloom taksonomisine göre incelenmesi. Uludă̆ Üniversitesi Eğitim Fakültesi Dergisi, 30(2), 521-549.

Akcay, B., Akcay H., \& İnaltekin, T. (2018). Content Analysis of Science Textbooks' Evaluation Questions Based on Physics, Chemistry, Biology, Environment and Astronomy Subject Area by Bloom's Taxonomy. The Eurasia Proceedings of Educational \& Social Sciences (EPESS), 9, 71-78.

Akçay, H, Kapıcı, H., \& Akçay, B. (2020). Analysis of the representations in Turkish middle school science textbooks from 2002 to 2017. Participatory Educational Research, 7(3), 192-216.

Akkaya, G. (2016). Ortaöğretim dokuzuncu sınıf matematik ders kitaplarının öğretim programına uygunluğu açısından incelenmesi Yayınlanmamış yüksek lisans tezi. Akdeniz Üniversitesi, Eğitim Bilimleri Enstitüsü, Antalya.

Alkan, S. (2016). Matematik ögrretmenlerinin kullandıkları örneklerin sinıflandırılması ve öğretimsel açıklama boyutlarıyla ilişkisinin incelenmesi Yayınlanmamış doktora tezi. Karadeniz Teknik Üniversitesi, Eğitim Bilimleri Enstitüsü, Trabzon.

Aslan, O., Zor, T. Ş., \& Zor, E. (2019). Analyzing of 5th grade science textbooks in terms of measurement and assessment techniques. Çukurova Üniversitesi Ĕ̆itim Fakültesi Dergisi, 48(1), 737-756.

Bakırcı, H., \& Öçsoy, K. (2017). An investigation of the activities in science textbooks in terms of the concept of entrepreneurship. Adlyaman University Journal of Educational Sciences, 7(2), 256-276.

Ball, D. L., \& Cohen, D. K. (1996). Reform by the book: What is—or might be-the role of curriculum materials in teacher learning and instructional reform? Educational Researcher, 25(6), 8-14.

Bansiong, A. J. (2019). Readability, content, and mechanical feature analysis of selected commercial science textbooks intended for third grade filipino learners. Cogent Education, 6(1), 1706395. 
Baş, T. \& Akturan, U. (2008). Nitel araştırma yöntemleri NVivo 7.0 ile nitel veri analizi. (1. bask1). Ankara: Seçkin Yayıncılık.

Bauman, R. P. (1992). Physics that textbook writers usually get wrong, II. Heat and energy. The Physics Teacher, 30, 353-356.

Binns, I. C. (2013). A Qualitative Method to Determine How Textbooks Portray Scientific Methodology. In M. S. Khine (Eds.), Critical Analysis of Science Textbooks (pp. 239-258). Dordrecht: Springer.

Binns, I. C., \& Bell, R. L. (2015). Representation of scientific methodology in secondary science textbooks. Science \& Education, 24, 913-936.

Bowen, A. G. (2009). Document analysis as a qualitative research method. Qualitative Research Journal, 9(2), 27-40.

Civan, B. ve Biltekin, Ö. (2020). Açık öğretim ortaokulu fen bilimleri 5. sınıf. MEB yayınları.

Çakıcı, Y., \& Girgin, E. (2012). İlköğretim II. kademe fen ve teknoloji ders kitaplarındaki ünite sonu değerlendirme sorularının incelenmesi. Erzincan Üniversitesi Ĕ̆itim Fakültesi Dergisi, 14(2), 87-110.

Davis, E. A., \& Krajcik, J. (2005). Designing educative curriculum materials to promote eacher learning. Educational Researcher, 34(3), 3-14.

Devetak, I., \& Vogrinc, J. (2013). The criteria for evaluating the quality of the science textbooks. In M. S. Khine (Eds.), Critical analysis of science textbooks: Evaluating instructional effectiveness (pp. 3-15). New York, NY: Springer.

Dikmenli, M. (2010). An analysis of analogies used in secondary school biology textbooks: Case of Turkey. Eurasian Journal of Educational Research, 10(41), 73-90.

Duschl, R. A., Schweingruber, H. A., \& Shouse, A.W. (2007). Taking science to school: Learning and teaching sciencein grades K-8. Washington, DC: National Academy Press.

Gilbert, J. K. (2007). Visualization: A metacognitive skill in science and science education. In J. K. Gilbert (Eds.), Visualization in science education (pp. 9-28). Dordrecht, The Netherlands: Springer.

Güneş, B. (2017). Doğru bilinen yanlışlardan, yanlı̧̧ bilinen doğrulara: fizikte kavram yanılgıları. Palme Yayıncilık.

Inaltekin, T., \& Goksu, V. (2019). A Research on Visual Learning Representations of Primary and Secondary Science Textbooks in Turkey. International Journal of Progressive Education, 15(6) 51-65. 
Inaltekin, T., Özyurt, B., \& Akçay, H. (2012). Analysis of activities in elementary 6th, 7th and 8th grade science and technology textbooks. Trakya University Journal of Education, 2(2), 63-73.

Irez, S. (2009). Nature of science as depicted in Turkish biology textbooks. Science Education, 93, 422-447.

Işık, C. (2008). İlköğretim ikinci kademesinde matematik öğretmenlerinin matematik ders kitabı kullanımını etkileyen etmenler ve beklentileri. Kastamonu Eğitim Dergisi, 16(1), 163-176.

Kapıcı, H. Ö., \& Savaşçı-Açıkalın, F. (2015). Examination of visuals about the particulate nature of matter in Turkish middle school science textbooks. Chemistry Education Research and Practice, 16(3), 518-536.

Kavcar, N. ve Erdem, A. (2017). Fizik öğretim programları ile fizik ders kitaplarının proje tabanlı öğrenme açısından incelenmesi. Online Fen Eğitimi Dergisi, 2(1), 11-44.

Khine, M. S., \& Liu, Y. (2017). Descriptive analysis of the graphic representations of science textbooks. European Journal of STEM Education, 2(3), 1-15.

King, C. J. H. (2010). An analysis of misconceptions in science textbooks: Earth science in England and Wales. International Journal of Science Education, 32(5), 565-601.

Kovač, M., \& Kovač Šebart, M. (2004). Učbeniki v postsocialističnih državah: nastavki za primerjalno analizo. Knjižnica, 48(3), 7-31.

Li, X., Tan, Z., Shen, J., Hu, W., Chen, Y., \& Wang, J. (2018). Analysis of five junior high school physics textbooks used in China for representations of nature of science. Research in Science Education, 50, 833-844.

Lin, J. W. (2016). Do skilled elementary teachers hold scientific conceptions and can they accurately predict the type and source of students' preconceptions of electric circuits? International Journal of Science and Mathematics Education, 14(2), 287-307.

Liu, Y., \& Khine, M. S. (2016). Content analysis of the diagrammatic representations of primary science textbooks. Eurasia Journal of Mathematics, Science \& Technology Education, 12(8), 1937-1951.

McDonald, C. V. (2016). Evaluating junior secondary science textbook usage in Australian schools. Research in Science Education, 46(4), 481-509.

McDonald, C. V., \& Abd-El-Khalick, F. (2017). Representations of nature of science in school science textbooks. In C. V. McDonald \& F. Abd-El-Khalick (Eds.), Representations of 
nature of science in school science textbooks: A global perspective (pp. 1-19). New York: Routledge.

Miles, M. B., \& Huberman, A. M. (1994). Qualitative data analysis: An expanded sourcebook. Beverly Hills: Sage Publications.

Moodley, K., \& Gaigher, E. (2017). Teaching electric circuits: Teachers’ perceptions and learners' misconceptions. Research in Science Education, 49, 73-89.

Morris, B. J., Masnick, A. M., Baker, K., \& Junglen, A. (2015) An analysis of data activities and instructional supports in middle school science textbooks. International Journal of Science Education, 37(16), 2708-2720.

Mullis, I. V., Martin, M. O., Minnich, C. A., Stanco, G.M., Arora, A., Centurino, V. A., \& Castle, C. E. (Eds.). (2012). TIMSS 2011 encyclopedia: Education policy and curriculum in mathematics and science (Vol. 1). Amsterdam: International Association for the Evaluation of Educational Achievement.

Nabi, M., \& Iqbal, M. J. (2018). Parameters for Textbook: Improving Quality of Primary Education. Global Social Sciences Review, 3(4), 187-200.

Nakiboğlu C., (2009), Deneyimli kimya öğretmenlerinin ortaöğretim kimya ders kitaplarını kullanımlarının incelenmesi. Ahi Evran Üniversitesi Kırșehir Eğitim Fakültesi Dergisi (KEFAD), 10(1), 1-10.

Nie, Y., Xiao, Y., Fritchman, J. C., Liu, Q., Han, J., Xiong, J., \& Bao, L. (2019). Teaching towards knowledge integration in learning force and motion. International Journal of Science Education, 41(16), 2271-2295.

Ozaskin Arslan, A. G., \& Ulucinar Sagir, S. (2020). Representation of nature of science in matter and its nature subject area of science textbooks, International Online Journal of Educational Sciences, 12(5), 124-143.

Park, D., \& Lavonen, J. (2013). An analysis of standards-based high school physics textbooks of Finland and the United States. In M.S. Khine (Eds.), Critical analysis of science textbooks: Evaluating instructional effectiveness (pp.219-238). Dordrecht, The Netherlands: Springer.

Rohmah, R. S., Fariati, \& Ibnu, S. (2020). Effect of conceptual change texts on physical inorganic chemistry students' misconceptions of matter and its changes. AIP Conference Proceedings, 225(1), p. 20020.1-7. AIP Publishing LLC.

Quasim, S. H., \& Pandey, S. S. (2017). Content analysis of diagrammatic representations in upper primary science textbooks. International Journal of Research, 5(7), 474-479. 
Sadoski, M. (2001). Resolving the effects of concreteness on interest, comprehension, and learning important ideas from text. Educational Psychology Review, 13(3), 263-281.

Sari, D. R., Ramdhani, D., \& Surtikanti, H. K. (2019, February). Analysis of elementary school students' misconception on force and movement concept. In Journal of Physics: Conference Series (Vol. 1157, No. 2, p. 022053). IOP Publishing.

Schizas, D., Papatheodorou, E., \& Stamou, G. (2018). Transforming “ecosystem” from a scientific concept into a teachable topic: Philosophy and history of ecology informs science textbook analysis. Research in Science Education, 48(2), 267-300.

Simpson, D. Y., Beatty, A. E., \& Ballen, C. J. (2021). Teaching between the Lines: Representation in science textbooks. Trends in Ecology \& Evolution, 36(1), 4-8.

Stern, L., \& Roseman, J. E. (2004). Can middle-school science textbooks help students learn important ideas? Findings from project 2061's curriculum evaluation study: Life science. Journal of Research in Science Teaching, 41(6), 538-658.

Taş, M., Bozdoğan, A. E. ve Tekbıyık, A. (Ed.). (2019). Ortaokul ve imam hatip ortaokulu fen bilimleri ders kitabı 5. sinıf. MEB yayınları.

Tikly, L. \& Barrett, A. (2009). Social justice, capabilities and the quality of education in low income countries. (EdQual Working Paper No. 18). Bristol: University of Bristol.

Uçar, C., \& Somuncuoğlu Özerbaş, D. (2017). Evaluation of the secondary school 5th grade science textbooks according to visual design principles. Kastamonu Ĕ̌itim Dergisi, 25(4), 1373-1388.

Upahi, J. E., Ramnarain, U., \& Ishola, I. S. (2018). The nature of science as represented in chemistry textbooks used in Nigeria. Research in Science Education, 50, 1321-1339.

Ünsal, Y., \& Güneş, B. (2002). Bir kitap inceleme çalışması örneği olarak MEB ilköğretim 4. sınıf fen bilgisi ders kitabına fizik konuları yönünden eleştirel bir bakış. Gazi Üniversitesi Gazi Eğitim Fakültesi Dergisi, 22(3), 107-120.

Ünver, E., Yanc1, M. V. ve Arslan, Z. (2019). Ortaokul ve imam hatip ortaokulu fen bilimleri ders kitabı 5. sinıf. Dikey yayınc1lık.

Valanides, N., Papageorgiou, M., \& Rigas, P. (2013). Science and science teaching. In M. S. Khine (Eds.), Critical analysis of science textbooks (pp. 259-286). Springer.

Wach, E., Ward, R., \& Jacimovic, R. (2013). Learning about qualitative document analysis. Institute of Development Studies Paper in Brief 13, (2008, September, pp. 1-10). Retrieved from https://www.ids.ac.uk/publications/learning-about-qualitative-document-analysis 
Widiyatmoko, A., \& Shimizu, K. (2018). Literature review of factors contributing to students’ misconceptions in light and optical instruments. International Journal of Environmental and Science Education, 13(1), 853-863.

Yacoubian, H., Al-Khatib, L., \& Mardirossian, T. (2017). Analysis of the 1mage of scientists portrayed in the Lebanese national science textbooks. Science \& Education, 26, 513-528.

Yang, S., Park, W., \& Song, J. (2020). Representations of nature of science in new Korean science textbooks: The case of ‘scientific inquiry and experimentation'. In A. L. Tan, T. W. Teo, \& Y. S. Ong (Eds.), Science education in the 21st century: Re-searching issues that matters from different lenses. Singapore: Springer.

Zajkov, O., Gegovska-Zajkova, S., \& Mitrevski, B. (2017). Textbook-caused misconceptions, inconsistencies, and experimental safety risks of a grade 8 physics textbook. International Journal of Science and Mathematics Education, 15(5), 837-852.

\section{Extended Abstract}

\section{Introduction}

Textbooks are the primary learning tools among the sources of information for students. These books are always parts of students' individual activities and are necessary at all stages of the learning process (Devetak \& Vogrinc, 2013). It is very important to use examples in science lessons to make the concepts of the subjects more understandable. Examples are special cases used to explain the non-conceptual situations as well as the definitions of the concepts (Alkan, 2016). The examples of subject preferred in the science textbooks affect the students' acquisition of scientific knowledge in a proper and more understandable way. In this study, the types of examples given in various secondary school 5th grade textbooks used for teaching sciences subjects in Turkey were compared. In this context, it is thought that the study will shed light on how effectively the examples preferred in the science textbooks of the secondary school 5th grade students to teach physics subjects are prepared and whether there is a variety of examples in these books. 


\section{Method}

Document analysis, one of the qualitative research designs describing the types of examples used in teaching physics subjects in the secondary school 5th grade science textbooks was used in the study. Within the scope of the study, three textbooks prepared by the Board of Education and Discipline within the framework of the regulations propounded by the private publishing house and the Ministry of Education to be used in the 5th grade science lessons in the 2020-2021 academic year were examined as documents. The types and usage frequencies of examples in the units covering physics subjects in the textbooks were analyzed as per each learning outcome. Secondly, the types of examples were compared in terms of all three types of books. The example classification systematic developed by Alkan (2016) was used for the examples given in the units reviewed.

\section{Results}

The findings obtained as a result of analyzing the examples set on the units of "Measurement of Force and Friction, Matter and Change, Propagation of Light and Electrical Circuit Components" in the books suggested by the Ministry of National Education to be used in science lessons in the secondary school 5th grade in the 2020-2021 academic year were presented in this section. The units of "Measurement of Force, Matter and Change, Propagation of Light and Electrical Circuit Elements" in the 5th grade science textbooks were examined, and it was found that there were 68 examples in the textbook coded FK1, 71 in FK2 and 80 in FK3. Furthermore, it was determined that in the relevant units in the textbooks coded FK1, FK2 and FK3, extreme, non-exemplary and counter examples were not used. Within the scope of the measurement of force and friction unit, 24 examples were used in FK1, 21 in FK2 and 23 examples in FK3 in total. Within the scope of the relevant unit, it was also determined that BK3, SK2, SK3 and GK3 types of examples were not used in these three books. Within the scope of the matter and change unit, 29 examples were used in FK1, 37 in FK2 and 37 in FK3 in total. Within the scope of the relevant unit, it was determined that BK3 and SK2 types of examples were not used in these three books. Within the scope of the propagation of light unit, it can be seen that 12 examples were used in FK1, 12 in FK2, and 19 in FK3. Furthermore, it can be seen within the scope of the electrical circuit components unit that three examples were used in FK1, and one example was used in FK2 and FK3. It was determined that the standard examples were not used in the textbooks as well. 


\section{Discussion and Conclusion}

Three textbooks used in the secondary school 5th grade science courses in Turkey in the 2020-2021 academic year were compared in terms of the examples preferred for teaching physics subjects in this study. It was found that the preferred examples for teaching physics subjects in the 5th grade science textbooks in Turkey consist of mostly standard examples in terms of physics subjects covered in all three books. It was also determined that the beginner level and developmental examples were preferred less amounts in teaching all physics subjects. Notwithstanding, it was seen that extreme, non-exemplary and counter examples were not included in all three books for teaching physics subjects. As a result of the comparison made in terms of all three types of books, it was understood that the stated results stand out more in the textbook coded FK3 (Open Education) compared to the other two books. It was observed that approximately the same number of examples were used for teaching the subjects in the unit "Measurement of Force and Friction" in all three books. Furthermore, it was understood that the examples in this unit included beginner, standard, and improving examples. Considering these results, it can be said that the use of counter examples along with the beginner, standard and improving examples preferred within the scope of this unit will be effective in preventing students from learning inaccurately. It can be seen in the related literature that students have many alternative concepts regarding the force and friction unit in the teaching of physics subjects (Nie, Xiao, Fritchman, Liu, Han, Xiong \& Bao, 2019; Sari, Ramdhani, \& Surtikanti, 2019). As a result of the evaluation of the examples used in the textbooks within the scope of the "Matter and Change" unit, it was found that the total number of samples used in FK2 and FK3 was higher than in FK1. It was understood that the examples used in these three books were generally beginner, standard and improving types of examples and that mostly standard examples were included. Furthermore, it was determined that the beginner examples were not included that much in the textbook coded FK1. Due to the intensity and complexity of the "Matter and Change” unit, it is inevitable that students' attention and motivation will decrease. This can be eliminated by increasing the number and variety of examples facilitating the understanding of the informational content on the subject of "Matter and Change" in science textbooks for secondary school students. According to the evaluation of the examples used in the textbooks within the scope of the unit "Propagation of Light", it was seen that the total number of examples used in FK3 was higher than that of FK1 and FK2. Since the subjects in the related unit contain abstract concepts, they should be assisted with rich examples that will enable students to make sense of these concepts and expand their 
YYÜ Eğitim Fakültesi Dergisi (YYU Journal of Education Faculty), 2021;18(2)81-110,http://efdergi.yyu.edu.tr,

possible perceptions (Widiyatmoko \& Shimizu, 2018). In the evaluation of the examples used in the textbooks within the scope of the "Electrical Circuit Components" unit, it was seen that the use of examples in all three books was very limited. It was also determined that the unit of "Electrical Circuit Components" contained quite a few examples and types of examples compared to other units. Considering these results, it can be understood that the textbooks need to be enriched in terms of the diversity of examples preferred in teaching "Electrical Circuit Components" subjects. 